\title{
Effects of a Gonadotropin Mixture on Reproductive Success in Progesterone- Treated Non-Lactating Anestrous Ewes
}

Kellie Nicole D'Souza
West Virginia University

Follow this and additional works at: https://researchrepository.wvu.edu/etd

\section{Recommended Citation}

D'Souza, Kellie Nicole, "Effects of a Gonadotropin Mixture on Reproductive Success in ProgesteroneTreated Non-Lactating Anestrous Ewes" (2013). Graduate Theses, Dissertations, and Problem Reports. 3608.

https://researchrepository.wvu.edu/etd/3608

This Thesis is protected by copyright and/or related rights. It has been brought to you by the The Research Repository @WVU with permission from the rights-holder(s). You are free to use this Thesis in any way that is permitted by the copyright and related rights legislation that applies to your use. For other uses you must obtain permission from the rights-holder(s) directly, unless additional rights are indicated by a Creative Commons license in the record and/ or on the work itself. This Thesis has been accepted for inclusion in WVU Graduate Theses, Dissertations, and Problem Reports collection by an authorized administrator of The Research Repository @ WVU. For more information, please contact researchrepository@mail.wvu.edu. 
Effects of a Gonadotropin Mixture on Reproductive Success in ProgesteroneTreated Non-Lactating Anestrous Ewes

Kellie Nicole D'Souza

Thesis submitted to the Davis College of Agriculture, Natural Resources and Design at West Virginia University in partial fulfillment of the requirements for the degree of

Master of Science in Reproductive Physiology

Marlon Knights, Ph.D., Chair

Robert A. Dailey, Ph.D.

E. Keith Inskeep, Ph.D.

Doolarie Singh-Knights, Ph.D.

Division of Animal and Nutritional Sciences

Morgantown, West Virginia

2013

Keywords: Anestrus; Ewe; Fertility; P.G. $600^{\circledR}$

Copyright 2013 Kellie Nicole D'Souza 


\title{
ABSTRACT \\ Effects of a Gonadotropin Mixture on Reproductive Success in Progesterone- Treated Non-Lactating Anestrous Ewes
}

\author{
Kellie Nicole D’Souza
}

\begin{abstract}
Using exogenous gonadotropins as part of an estrous induction protocol can have beneficial effects on fertility in ewes bred out-of-season. Few studies have evaluated the efficacy of P.G. $600^{\circledR}$, a mixture of gonadotropins with FSH-like and LH-like activity, to increase fertility in anestrous ewes and, in particular, following pre-treatment with progesterone delivered via controlled internal drug releasing (CIDR) devices. The objective of this study was to evaluate the effects of P.G. $600^{\circledR}$ on reproductive success in progesterone-treated non-lactating anestrous ewes. Ewes, which had been separated from rams for at least one month prior to the beginning of the experiment, received CIDR inserts five days prior to introduction of rams. In the first experiment, ewes were assigned randomly to receive either a 3 $\mathrm{mL}$ injection of P.G. $600^{\circledR}$ [i.m., $240 \mathrm{IU}$ equine chorionic gonadotropin (eCG) and $120 \mathrm{IU}$ human chorionic gonadotropin (hCG)] at CIDR insert removal or no further treatment. In the second experiment, ewes were assigned randomly to receive either a $3 \mathrm{~mL}$ injection of P.G. $600^{\circledast}$ one day prior to insert removal or no further treatment. In experiment 1 , incidence of estrus was significantly greater for treated ewes than control ewes, while prolificacy (number of lambs born per ewe lambing) tended to be higher in treated ewes. In experiment 2, treated ewes had significantly higher conception rates and pregnancy rates to first service and tended to have higher overall pregnancy rates than control ewes. A greater percentage of ewes lambed in the treated group than in the control group; however, prolificacy was not different between the groups. In addition, overall lambing rates in ewes treated with P.G. $600^{\circledR}$ were significantly higher than those of the control group. An injection of $3 \mathrm{~mL}$ of P.G. $600^{\circledR}$ (240 IU eCG and 120 IU hCG) one day prior to CIDR removal significantly increased reproductive success in progesteronetreated non-lactating anestrous ewes. Further, the gonadotropin injection was determined to be economically beneficial.
\end{abstract}




\section{TABLE OF CONTENTS}

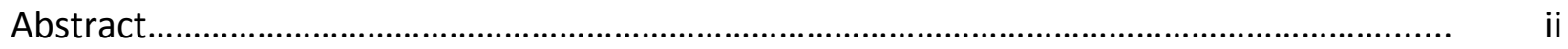

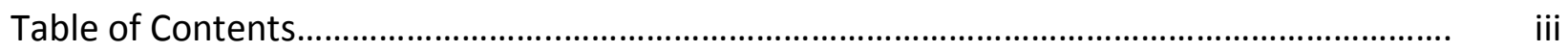

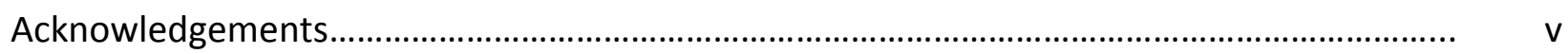

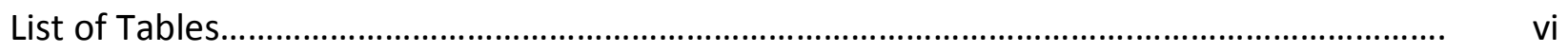

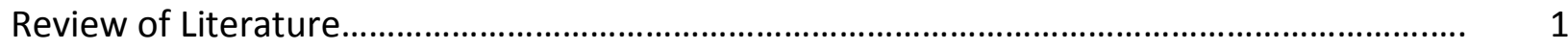

The Status of the Sheep Industry in the United States................................................ 1

Seasonality of Reproduction in Sheep.........................................................................

The Effects of Day Length (Photoperiod)

The Effects of Temperature

Resumption of Reproductive Activity

Factors Affecting Reproductive Success in Ewes....................................................... 8

Age of Ewe and Ram

Breed of Sheep

Lactational Status of Ewe

Nutritional Effects in the Ewe and Ram

Ram to Ewe Ratio

Ram Selection

Methods of Inducing a Fertile Estrus in Ewes Bred Out-of-Season...............................

Ram Effect

Progesterone Pre-Treatment

Use of Gonadotropin Co-treatments in Ewes Bred Out-of-Season

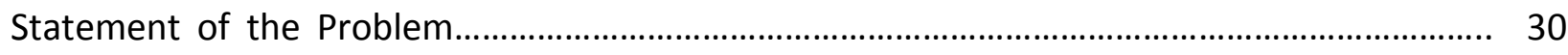

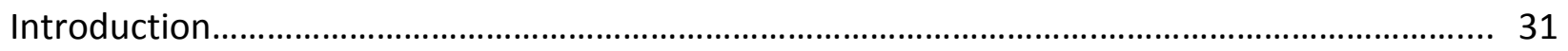


Materials and Methods...

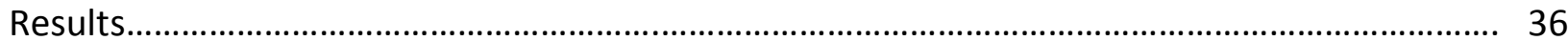

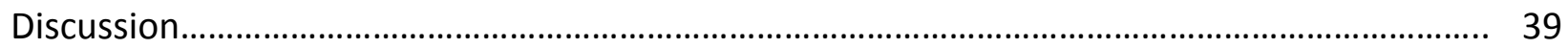

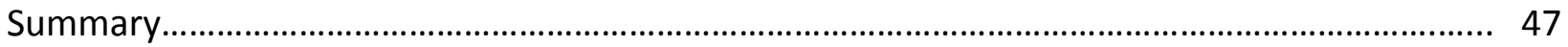

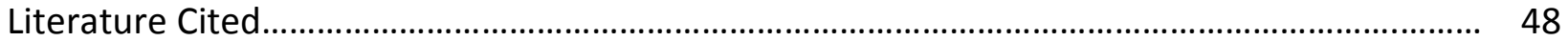

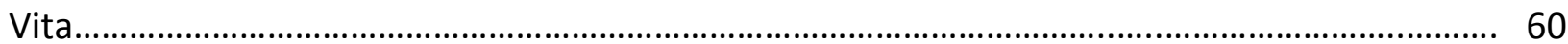

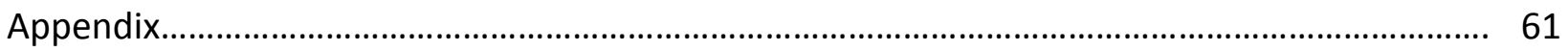




\section{ACKNOWLEDGEMENTS}

I would like to thank my mentor, Dr. Marlon Knights, for his guidance, enthusiasm, support, and patience during my "longer-than-expected" master's level graduate training. Not only was Dr. Knights instrumental in my success as a scientist, but also as an individual. I also wish to express thanks to Dr. E. Keith Inskeep for his constructive criticism and informal grammar tutorials. I wish to thank Dr. Robert A. Dailey for helping me think deeper in the field of Reproductive Physiology and his ability to make me laugh. I also wish to thank Dr. Doolarie "Dee" Singh-Knights for her support and for helping me better understand the risks associated with livestock management.

I am forever indebted to my fellow lab members, Dr. Quinn Baptiste, Adam Redhead, and Stephanie Simpson, for their help with fieldwork, data collection, and endless hours of travel to and from farms. Without the help of my lab members, this project would not have been possible. I also wish to express thanks to my fellow graduate students who graciously volunteered their time to help with the fieldwork and data collection for my project.

I would like to thank the cooperating sheep producers who volunteered the use of their animals for the project. Without their help and patience, this project would not have been possible. Specifically, I want to thank Seth Hines and the crew from Reymann Memorial Farms in Wardensville for their help and for providing a fun working atmosphere. I would also like to thank George and Lisa Wherry for their tremendous work ethic and warm hospitality. Additionally, I wish to thank Ed Cokeley, Jimmy and Portia Dean, Mark Teets, and Marvin Warner for their support and for their willingness to work with us.

Finally, I would like to thank my family for their unwavering love, support, encouragement, and motivation throughout my graduate studies. 


\section{LIST OF TABLES}

Table 1. Location, breed, and number of animals used for Experiments 1 and 2.

Table 2. Effects of P.G. $600^{\circledR}$ administered at CIDR removal on reproductive responses in non-lactating ewes treated with a CIDR 5 days prior to ram introduction during the anestrous period....... 36

Table 3. Effects of P.G. $600^{\circledR}$ administered one day before CIDR removal on reproductive responses in non-lactating ewes treated with a CIDR 5 days prior to ram introduction during the anestrous period.. 37 


\section{REVIEW OF LITERATURE}

\section{The Status of the Sheep Industry in the United States}

Since the mid-1940s, the sheep inventory in the United States has been in decline, and the market for sheep products has shifted from wool to meat (Jones, 2004). In a recent article, Dumas (2011) reported that demand for lamb has become increasingly inelastic; that is, buying habits are not dependent upon price, as they had been previously, but more upon quality of the product. Furthermore, consumers are not substituting other proteins, such as beef, for lamb, as they had done in the past. As a result, the market for lamb in the United States is growing and is driven by demand of ethnic markets. In terms of economics, the supply of lamb is driven by demand; however, demand is not supply-driven, meaning prices will stay high. The combination of decreased imports and expanding ethnic markets has led to the recent prosperity of lamb markets in the United States. (Dumas, 2011).

Because of the shift in the volume and nature for demand for sheep products, a need exists for an increase not only in number of sheep, but also in quantity of sheep products produced. However, farmers and processors share concern about meeting the demand of the market in the United States. In an effort to increase the inventory of sheep, the American Sheep Industry (ASI) Association has proposed a program called "Let's Grow with twoPLUS." The primary objective of this campaign is to encourage current producers to expand their sheep numbers in the next few years. The three goals of ASI are to encourage producers to increase the size of their operation by two ewes per 100 head by 2014, to increase the average birthrate per ewe to two lambs per year, and to increase the harvested lamb crop by 2 percent - from 108 percent to 110 percent.

In addition to increasing the number of sheep, a more consistent supply of lamb is needed to meet the demand for the product, which tends to be highest just before ethnic and religious holidays, 
such as Easter/Passover (Jones, 2004). To provide a consistent supply of lamb, some producers must be willing to alter the management of their flocks to facilitate year-round supply.

In an industry that is increasingly competitive and risky, it is necessary to increase total revenue to stay in business. The traditional production system employed by most sheep producers results in the majority of lambs marketed when annual prices are lowest. In West Virginia, the price of lamb is lowest between August and October, which is when the highest percentage of lambs is sold (Singh-Knights, 2003). By shifting to out-of-season breeding, producers could take advantage of higher lamb prices.

In addition to increased revenue, another benefit of adopting out-of-season breeding is the potential for a decrease in loss of lambs due to predation and parasitism. The gestation period of a ewe is about five months, so by breeding ewes in the summer, the lambs will be born in the winter when losses due to predation are lowest. With traditional sheep production systems, lambs are on pasture during the spring and summer months, which coincides with the period of greatest predation by coyotes (Singh, 2000). Singh (2000) showed that predation accounts for 83 percent and 30 percent of all losses in lambs and ewes, respectively. Loss of lambs due to predation has been one of the major reasons producers in West Virginia were forced to exit the sheep industry (Singh, 2000). Lambs on pastures during late spring and summer months also are exposed to the peak in parasite loads, resulting in reduced growth rates and higher mortality rates (Miller et al., 1998). Shifting to an out-of-season breeding system would not only reduce loss of ewes and lambs due to predation, but also could limit exposure of lambs to parasites.

With a traditional breeding system, the efficiency of a flock of ewes is not maximized; typically only one lamb crop is produced per year, and, on average, only 1.1 lambs are marketed per ewe (WVDA, 2010). Out-of-season breeding can be used as part of an accelerated breeding program, thus increasing the productivity of ewes by enabling them to produce three lamb crops in two years (Cameron et al., 
2010), which could lead to an increase in profitability. In addition, breeding out-of-season could lead to an increase in the size of the operation and more animals would be bred per year, potentially leading to a further increase in profitability. The profitability of sheep enterprises might also increase by finishing market lambs in larger and more even groups (Buckrell, 1987).

Although many benefits of out-of-season breeding exist, the use of this production system among sheep producers in West Virginia remains low. By increasing adoption of this management system, the maximum potential of the sheep industry can be achieved, and the increasing demand for lamb products during ethnic holidays can be met.

In summation, the United States sheep industry has experienced a significant decline in inventory and in sheep production. Presumably, the decline in production is due to a number of factors, such as low profitability of sheep enterprises, increased competition in demand between markets, loss of animals due to predation and parasitism, and low productivity of ewes. Some of these factors are associated with the seasonal nature of reproduction in the ewe. Attempts to shift the seasonal pattern of reproduction have been partly successful, but the lambing rate is still lower than is observed during the breeding season. Approaches that enhance the fertility of ewes bred out-of-season can further increase profitability of producers, leading to increased production and revitalization of the sheep industry.

\section{Seasonality of Reproduction in Sheep}

Sheep have a marked seasonal pattern of breeding activity and are classified as seasonally polyestrous animals. In the Northern Hemisphere, this period of reproductive cyclicity begins in August and typically lasts until February. Both the daily photoperiod and the annual cycles in environmental 
temperature play an important role in the seasonality of reproduction in sheep in temperate regions, while the annual cycle in rainfall, with the consequent cycles in food availability, is of the greatest importance in tropical regions (Vivien-Roels and Pévet, 1983).

\section{A. The Effects of Day Length (Photoperiod)}

The effects of environmental factors, such as day length and temperature, were first reported by Marshall (1937). He observed that moving ewes across the equator resulted in a gradual reversal of their reproductive patterns as they adapted to the new environment. The photoperiod can be successfully manipulated to reverse the normal seasonal variation in reproduction (Thwaites, 1965). Estrous activity was observed in Southdown ewes that were exposed to natural light, reversed seasonal lighting, or equatorial lighting for a period of two years. Control ewes showed a restricted breeding season that was between the autumn and winter months of each year, while artificial reversal of the normal seasonal variation in day length resulted in the almost complete reversal of the natural breeding season. Thus, the photoperiod plays a critical role in controlling reproductive activity in sheep.

Lincoln and Davidson (1977) reported that in Soay rams, which were housed under artificial lighting conditions with alternating 16 -week periods of long and short days, concentrations of LH and FSH began to increase two to four weeks after the abrupt change in photoperiod (from long to short days), and almost immediately following this increase in gonadotropins was a rise in plasma testosterone accompanied by growth of the testes. In addition to changes in gonadotropin secretion, rams exhibit seasonal variation in libido (Shackell et al., 1977). The libido of rams tended to be lower at the end of the breeding season and during the non-breeding season as compared to the beginning of the breeding season, leading to the assumption that the breeding season of Soay rams tends to be shorter than that of ewes. The authors concluded that although a seasonal variation in libido in rams exists, it is unlikely to limit the success of out-of-season breeding. 
In most breeds of sheep, photoperiod determines whether or not the sheep are reproductively active by controlling the release of the hormone, melatonin. During short days (i.e. long nights, August through February in the Northern Hemisphere), the pineal gland secretes melatonin (a hormone secreted only during the hours of darkness) for a longer duration as compared to long days (i.e. short nights, March through July in the Northern Hemisphere). The requirement of the pineal gland in photoperiodic control of reproduction of ewes was determined via pinealectomy (Bittman et al., 1983). In most animals, removal of the pineal gland not only eliminated both the stimulatory effects of short days and the inhibitory effects of long days, but also the nighttime rise in serum melatonin.

The exact mechanisms by which melatonin controls reproductive functions are not known. However, receptors for the hormone have been found in a number of neural areas, mostly near the base of the hypothalamus in an area known as the pars tuberalis (PT), which is located adjacent to the medial basal hypothalamus (MBH; Dardente, 2011). Binding studies with radioactive-labeled melatonin implants showed that more melatonin receptors ( 25 fold) are present in the PT as compared to the MBH (Bittman and Weaver, 1990). Although a majority of the melatonin receptors are found in the PT, it has been suggested that in sheep, melatonin controls gonadotropin release by acting on the posterior portion of the MBH (Goodman, 1999). Melatonin implants placed in the MBH of ewes housed under a long day photoperiod resulted in changes typical to those observed under a short day photoperiod, namely an increase in secretion of LH/FSH with a decrease in prolactin (Dardente, 2011). Collectively, these data indicate that while the majority of melatonin receptors are located in the PT, the MBH still plays a pivotal role in regulating the effects of melatonin on reproductive activity by mediating gonadotropin secretion. 


\section{B. The Effects of Temperature}

Temperature might affect reproductive activity in ewes. Ewes maintained under low temperatures during the summer began their reproductive season earlier than those kept under temperatures typical of that season (Dutt and Bush, 1955; Godley et al., 1966). However, WodzickaTomaszewksa et al. (1967) reported that ewes that were kept on a photoperiod of $12 \mathrm{~h}$ of light and $12 \mathrm{~h}$ of dark maintained normal reproduction when temperatures were seasonally reversed. The breeding activity of ewes also can be affected by heat stress. Heat stress causes a disruption in endocrine interactions, resulting in suppressed GnRH and LH pulse frequency and amplitude (Dobson et al., 2012). This group reported that heat stress can delay the onset of estrous behavior and lengthen the interval from estrus to the onset of the pre-ovulatory LH surge. This could have deleterious consequences for fertility.

Rams exhibit small seasonal fluctuations in sexual activity and hormone secretion (Schanbacher and Lunstra, 1976; Lincoln and Davidson, 1977). For example, while ewes completely cease sexual behavior during seasonal anestrus, rams will still exhibit sexual behaviors if placed in the presence of a ewe in estrus. The seasonal fluctuations seen in rams include changes in testes size, and quality and quantity of sperm produced. Both of which can be attributed to changes in temperature, but light remains the major regulatory factor (Pelletier and Almeida, 1987). In addition, prolonged exposure to high temperatures can not only cause lack of libido in rams, but also can affect the production of viable sperm (Schoenian, 2011). Resumption of reproductive activity in the male is controlled by an increased secretion of $\mathrm{LH}$, which results from a reduced response to the negative feedback effects of testosterone (Olster and Foster, 1988). During the non-breeding season of the mature Suffolk ram, testis size is reduced and fertility is decreased (Karsch et al., 1984). Nonetheless, rams of most breeds are able to mate at any time of the year, although both the lack of libido and the lower quality and quantity of 
ejaculate during the non-breeding season can reduce the efficacy of out-of-season breeding (Henderson and Robinson, 2000).

\section{Resumption of Reproductive Activity}

The length of the post-partum interval (PPI) in ewes is affected by a number of factors including nutrition (both pre- and post-partum), lactation and season (Dunn and Kaltenbach, 1980). Smith (1964) examined the effects of alfalfa supplementation on the length of the anestrous period in Peppin Merino ewes in Australia and reported that ewes that grazed poor quality pasture from lambing until midsummer had a higher percentage of anestrous ewes than those that received supplemental alfalfa hay.

The effects of the nutrition, body mass, and change in body mass on the PPI in fall-lambing Merino ewes were evaluated by Lishman et al. (1974). The authors reported that weight loss in mature ewes due to under-nutrition during lactation had little effect on the PPI or the percentage of anestrous ewes. Similar to mature ewes, weight loss caused by poor nutrition during lactation in primiparous ewes had no effect on the length of the PPI. However, there was a significant difference in the percentage of anestrous ewes in this younger, primiparous group leading to the suggestion that the effects of nutrition may be influenced by age.

Mandiki et al. (1990) studied the effects of suckling on endocrine control of resumption of reproductive activity in Texel ewes lambing in July or November. They reported that the resumption of ovarian and estrous activity was much earlier after the November lambing than after the July lambing. In addition, they found that weaning after the November lambing shortened the interval from parturition to first estrus, but not to the first luteal function. In another study, the onset of post-partum estrous activity was significantly delayed by lactation in Merino ewes (Smith, 1964). 
The economic importance of the length of the PPI of the ewe depends on the management system that is employed by the producer. In extensive range operations with breeding in late fall/early winter and lambing in late spring, the length of the PPI is of little importance. Conversely, in intensively managed farm flocks, especially those managed to produce more than one lamb crop in a given year, the length of the PPI becomes quite important (Dunn and Kaltenbach, 1980).

\section{Factors Affecting Reproductive Success in Ewes}

Many factors affect reproductive success in ewes, whether bred in season or during the seasonally anestrous period. Those factors include age, breed, lactational status, nutrition, ewe to ram ratio, and health of the ewe and ram. These factors heavily influence the reproductive variables that are typically measured (i.e. estrous response, conception rates, pregnancy rates, prolificacy, lambing rates, etc.) to determine the fertility and fecundity of ewes.

\section{A. Age of Ewe and Ram}

The effect of age of ewes on reproduction was first studied in 1935 by Cole and Miller, who reported that the breeding season for ewe lambs is shorter than for mature ewes. For a ewe lamb to successfully breed, the animal must first attain puberty, which is dependent on the time of year the lamb is born and the growth rate of the lamb (Dyrmundsson, 1973). Seventy-seven percent of Romney ewe lambs born in early April attained puberty in late October-early November with a mean age at puberty of 225 days (Abba and Lean, 2005). Conversely, attainment of puberty in fall-born ewe lambs was delayed until about 10 to 12 months of age (Vesely and Swierstra, 1987; Forcada et al., 1991).The growth rate of the lamb (i.e. weight) is an important factor in the timing of puberty. Gaskins et al. (2005) reported that the probability of pregnancy in ewe lambs (Columbia, Polypay, Rambouillet, and Targhee) increased as weight at breeding increased. 
Attempts to breed fall-born ewe lambs out-of-season have not been successful. Approaches used to evaluate the response have included ram introduction alone (Lopez-Sebastian et al., 1985), manipulation of the photoperiod (Ainsworth and Shrestha, 1987; Ainsworth et al., 1991), and use of gonadotropins in combination with progesterone and estradiol (Foote and Bennett, 1968). With ram introduction alone, fall-born ewe lambs exhibit "silent ovulations," where they are observed to ovulate, but often times do not exhibit estrus until the second or even third ovulation. When exposed to rams during the spring and early summer, only $11 \%$ of fall-born ewe lambs were bred compared to $59 \%$ of adult ewes derived from a line of Dorsets that was selected for fall lambing (Al-Shorepy and Notter, 1996), presumably because concentrations of estrogen receptors in the hypothalamus were not sufficient to induce estrous behavior in the lambs. Further, progesterone treatment alone failed to stimulate estrus and conception in fall-born ewe lambs (Burfening and Van Horn, 1970) seemingly because ram-induced secretion of gonadotropins was not sufficient to induce ovulation.

Using exogenous gonadotropins in estrous induction protocols could have beneficial effects on fertility in fall-born ewe lambs. Foote and Bennett (1968) induced estrus in fall-born ewe lambs at five and eight months of age, using a combination of estradiol on day one followed by daily injections of progesterone for 14 days and equine chorionic gonadotropin (eCG, formerly known as pregnant mare serum gonadotropin) two days after the last injection of progesterone. Using this treatment, $87 \%$ of the ewe lambs were in estrus and ovulated at eight months of age, and by 25 days after mating, $60 \%$ were pregnant. Burfening and Van Horn (1970) induced estrus in fall-born ewe lambs using a similar treatment to Foote and Bennett (1968), but with eCG on days 13,14, 15, 16, and 40. All treatments combining progestogen pre-treatment and eCG were effective in inducing a fertile estrus. Therefore, inducing a fertile estrus in fall-born ewe lambs during the non-breeding season seems to require supplementation with exogenous gonadotropins. 
Age of ewe may also affect cyclicity and ovulation rate. Mitchell (1998) studied the effects of age and dietary protein content on resumption of estrus and ovarian cyclicity during the post-partum period in autumn-lambing multiparous and primiparous ewes. They reported that multiparous ewes experienced a greater number of ovarian cycles and achieved higher ovulation rates than primiparous ewes. However, there was no effect of age or dietary protein content, within the range studied, on the onset of ovarian cyclicity.

The age of the breeding ram is also important. A five-month old ram lamb will breed some ewes, but will be much more effective at seven or eight months of age. In general, a ram lamb should be about $50-60 \%$ of his mature weight before he begins breeding. Also, ram lambs and mature rams should never be run together in the same breeding group. The older rams will dominate and may injure the younger rams (Schoenian, 2011). It is important to note that ram lambs reach sexual maturity earlier than ewe lambs (4-6 months vs. 6-8 months, respectively; Wooster and Hansen, 2005). This is imperative so that sperm can be produced and mature (spermatogenesis takes about 49 days in rams) by the time the ewe lambs attain sexual maturity (Ortavant, 1959).

\section{B. Breed of Sheep}

The length of the breeding season varies among breeds of sheep. Most breeds of sheep that originated in the tropics, and those with Merino ancestry, have longer breeding seasons than breeds of temperate and higher latitudes. A variety of breeds exist, each with different reproductive capabilities and the potential to improve flock performance. Examples of reproductive traits to select for to increase the fertility of a flock include extended breeding season (Dorset), early onset of puberty (Finnish Landrace), increased ovulation rate (Finnish Landrace, Romanov), and environmental suitability (Scottish Blackface; Gordon, 1983). 
Genetic selection of sheep for the ability to breed in the spring and summer can lead to increased fertility and maximize overall profitability of sheep enterprises. Notter (2002) selected a group of Dorset crosses for their ability to breed out-of-season and increased fertility over five generations. The proportion of ewes lambing after exposure to rams in May was increased from $50-60 \%$ to over $85 \%$ over the course of five generations.

\section{Lactational Status of Ewe}

Lactation suppresses estrous activity in the ewe. Suckling disrupts the normal pulsatile pattern of gonadotropin releasing hormone $(\mathrm{GnRH})$ secretion from the hypothalamus resulting in low concentrations of luteinizing hormone (LH). Follicle stimulating hormone (FSH) secretion returns to normal values early in lactation, and ovarian follicles continue to develop and mature. However, the follicles do not produce sufficient estrogen to induce an LH surge, which precedes ovulation, until suckling subsides (McNeilly, 1997). Conversely, dry ewes do not have the suckling stimulus to disrupt GnRH secretion and, thus, will resume estrous activity sooner than their lactating counterparts.

Mandiki et al. (1990) studied the effects of the overlapping of seasonal anestrus and lactation and the influence of the suckling mode on the resumption of reproductive activity in Texel ewes. They reported that the overlapping of seasonal anestrus and lactation delayed the resumption of ovarian and estrous activity. In early post-partum, suckling inhibited the LH pulsatile secretion and, consequently, the first LH surge. However, the effect is dependent on the time of year (Mauléon and Dauzier, 1965).

\section{Nutritional Effects in the Ewe and Ram}

The nutritional level of ewes during the winter and spring can influence the percentage of ewes showing estrus the following autumn (Smith, 1966). When maintained in a good body condition (BCS of 2.5 to 4) for 2 consecutive years, Forcada et al. (1992) found that the length of the anestrous period was 
reduced, indicating that good nutrition plays a role in resumption of estrous activity. In contrast, Gordon (1997) concluded that in both temperate and tropical breeds, the nutritional level appears to have little effect on the onset and duration of the breeding season. In the ram, inadequate nutrition leads to a decrease in testicular size and spermatogenic function (Martin and Walkden-Brown, 1995).

The mechanisms by which inadequate nutrition affects reproductive functions are poorly understood. However, some authors have reported that nutrition affects the secretion or clearance of certain hormones. For example, Adams et al. (1997) reported that under-nutrition affected the ovulation rate of ewes by disrupting the secretion of gonadotropins; Parr (1987) concluded that the clearance of progesterone was affected by overfeeding, and, thus, pregnancy rate was affected; and Boukhliq et al. (1996) found that the balance between FSH secretion and gonadal feedback was disrupted by inadequate nutrition, which altered the responsiveness of the anterior pituitary to the inhibitory effects of estradiol and inhibin.

Downing et al. (1995) reported that ovulation rate was increased in ewes that were fed a highenergy, lupin grain-supplemented diet. Lupin supplementation also significantly increased the plasma concentrations of insulin immediately after feeding, and they remained elevated for 24 hours. The sustained increases in insulin concentrations led to the suggestion that an increased supply of glucose to the follicle mediates nutritionally stimulated increases in ovulation rate. However, Bellows et al. (1963) examined the effects of sodium propionate on ovarian activity and found that the administration of the direct energy source produced no significant differences in follicular fluid weight.

\section{E. Ram to Ewe Ratio}

The number of ewes that a ram can breed in a 34- or 51-day breeding season (two or three estrous cycles) varies according to the age of the ram, breeding experience of the ram, the terrain in which the animals are kept, the size of the pasture, and the number of ewes that will be cycling at one 
time. A ram can usually mate three to four ewes per day. The recommended ram:ewe ratio for mature rams varies from 1:35 to 1:50. In large flocks, the ratio of rams to ewes is often lower. Ratios of 1:100 or 1:150 are common in some situations. Laster and Glimp (1972) synchronized estrus in 244 cycling Targhee ewes and exposed groups of them at ratios of 8, 12, 16, or 20 per ram. Surprisingly, they found no correlation between the number of ewes per ram and the percentage of ewes mated or the conception rate at the synchronized estrus. This study demonstrated that 1 ram per 20 ewes is sufficient for maximum mating activity and conception rate in ewes mated at a synchronized estrus. However, as demonstrated by Noakes et al. (2001), a higher ram:ewe ratio should be used when breeding at an induced and synchronized estrus in anestrous ewes because not only will there be more ewes to service in a shorter time frame, but also the semen quality and libido of rams are lower during the non-breeding season (Gouletsou and Fthenakis, 2010).

To maximize the fertility in a flock of ewes, the mating behavior patterns of sheep must be taken into account. Mature ewes that are in estrus tend to form groups around a ram and maintain close proximity (Gouletsou and Fthenakis, 2010), while younger ewes tend not to form groups and require more confinement and a greater number of rams for mating than mature ewes (Eilts, 2005). Furthermore, younger ewes are usually subordinate to adult ewes, which can reduce their chance of mating if run together with adult ewes; thus, separating younger ewes from mature ewes during the breeding period could lead to higher pregnancy rates (Smith and Knight, 1998). Enclosure size and topography are also important when assessing the ram:ewe ratio (Smith and Knight, 1998; Sargison, 2008; Gouletsou and Fthenakis, 2010).

Although most breeds of ram are able to mate year-round, semen quality and libido are decreased during the non-breeding season (Gouletsou and Fthenakis, 2010). Thus, if breeding out-ofseason, a higher than average ram:ewe ratio is required (Sargison, 2008). Furthermore, a higher than 
average ratio is required when estrus has been synchronized, even within the breeding season, because more ewes would be mated in a shorter time period (Gouletsou and Fthenakis, 2010). An even higher ratio should be used when estrous synchronization takes place out-of-season (Noakes et al., 2001).

\section{F. Ram Selection}

Reproductively superior rams will not only breed more ewes, but also have higher first service conception rates, lower early embryonic death rates, and improved lambing rates (Memon, 1983). To identify superior rams, breeding soundness examinations and observation of libido, intromission, and social behavior, could be performed on rams. Testicular palpation and measurement can be used to estimate sperm production potential (Notter et al., 1981). Scrotal circumference is directly related to sperm concentration in semen, sperm motility, and percent morphologically normal sperm (Walker, 1986).

Teaser rams, rams that have been vasectomized or epididymectomized, are useful to advance the breeding season, synchronize estrus in ewes, and detect return to estrus in non-pregnant ewes. For the teaser rams to be effective in breaking anestrus, they must be suddenly introduced to ewes that have not been in contact with rams for at least four weeks (Buckrell, 1987).

\section{Methods of Inducing a Fertile Estrus in Ewes Bred Out-of-Season}

\section{A. Ram Effect}

The most powerful and efficient tool used to cause ovulation in ewes bred out-of-season is the "ram effect," which was initially documented by Underwood et al. (1944). After about a month of isolation, introduction of rams to anovulatory ewes causes spontaneous ovulations between 24 and 48 hours after ram introduction; this phenomenon is known as the ram effect (Martin et al., 1986). Another 
group showed spontaneous ovulations closer to 64 hours after introduction of rams to anestrous ewes (Oldham and Martin, 1979). These spontaneous ovulations are generally not accompanied by estrus and often result in untimely luteal regression, followed by a second ovulation without estrus but with normal luteal function (Oldham and Martin, 1979). Thus, without the use of any additional treatments, ram introduction alone can lead to a fertile estrus about 18 to 24 days following the introduction of rams.

The ram effect has been identified in pre-pubertal ewes (Oldham and Gray, 1984; Kassem et al., 1989; Al-Mauly et al., 1991; Al-Shorepy and Notter, 1996; and Knights et al., 2002), lactating ewes (Mauléon and Dauzier, 1965; Poindron et al., 1980; and Silva and Ungerfeld, 2006), and seasonally anestrous ewes (Oldham et al., 1978; Martin et al., 1986; Wright et al., 1989; and Ungerfeld et al., 2004). The ram effect not only has the advantage of increasing the efficiency of breeding, allowing the reproductive season to be advanced by four to six weeks or more, but also can provide, to some extent, a synchrony of mating, and thus, of lambing (Rosa and Bryant, 2002).

The major stimuli that cause the ram effect in ewes are pheromones, which are naturally produced by rams. However, other stimuli, such as sight, hearing, and touch might be involved (Rosa and Bryant, 2002). Knight and Lynch (1980a) evaluated the sources of ram pheromones that stimulate ovulation in ewes. Rams' urine was sprayed over one group of ewes, wax collected from around the eyes and the bare skin of the rams' flanks was smeared on the nostrils of ewes in a second group, and wool recently shorn from rams was applied over the muzzle of ewes in a third group. The authors found that the wool and wax stimulated ovulation in a proportion of ewes similar to those exposed to rams, while urine failed to stimulate ovulation in a significant number of ewes. The site of synthesis of the pheromones appears to be the sudoriferous glands from where they are secreted with the suint, or the dried perspiration of sheep deposited in the wool (Knight and Lynch, 1980b). 
Exposure of ewes to pheromones produced by rams can induce either a chronic or an acute effect. In a chronic effect, the continuous presence of a ram can change the timing of both the onset and the end of the reproductive season, the duration of estrus in adult ewes, and the timing of puberty in ewe lambs (Rosa and Bryant, 2002). Donovan et al. (1991) reported that when ewes were kept in the presence of vasectomized rams during the entire breeding season, the breeding season ended about three weeks later and the onset of the subsequent breeding season was advanced by about one month, as compared to ewes that were not kept in the presence of rams throughout the breeding season. The period of anestrus was, therefore, shortened by about two months in ewes continually kept with rams. Also, the results of Sunderland et al. (1990) showed that the continuous presence of rams throughout the year delayed the date of the end of the reproductive season by about six weeks.

Ewes are receptive to rams during estrus for a shorter period of time when they are permanently associated with males, as opposed to when they are only allowed occasional contact (Parsons and Hunter, 1967; and Fletcher and Lindsay, 1971). Lindsay et al. (1975) showed that the continuous presence of rams throughout pre-estrus and estrus advanced ovulation, relative to the onset of estrus, by advancing the pre-ovulatory surge of $\mathrm{LH}$.

The acute effect caused by the contact of ewes with rams is known as the "ram effect," which is characterized by rapid increase in LH pulsatility in ewes as a result of the association with novel rams (Rosa and Bryant, 2002). Exposure of ewes to rams initiates the endocrine events that lead to ovulation, which occurs in most ewes within 50 hours of first contact with the rams (Martin et al., 1986). The endocrine events that lead to ovulation associated with the ram effect are similar to the normal follicular phase of a cyclic ewe. Upon introduction of the ram, there is an increase in LH pulse frequency accompanied by a decrease in pulse amplitude (Ungerfeld et al., 2004). It is well known that increased pulse frequency of LH is the critical step in the ram effect leading up to follicular development, estrogen 
production, the pre-ovulatory LH surge, and consequent ovulation. Interestingly, estrous behavior is not often associated with ovulation. In some ewes, the first heat occurs in conjunction with the second ovulation, about 17 to 20 days after ram introduction (Ungerfeld et al., 2004). In most ewes, there is an initial short luteal phase, then a second ovulation without any signs of estrus, followed by a normal luteal phase; in this case, estrus is associated with the third ovulation (Ungerfeld et al., 2004).

Ungerfeld et al. (2002) discovered the occurrence of delayed ovulation, about four to six days after ram introduction, using ultrasonography. By observing the ovaries, this group reported short luteal phases that were attributed to anovulatory follicles. These short luteal phases had been reported previously in pre-pubertal lambs (Berardinelli et al., 1980) and at the beginning of the breeding season in adult ewes (Ravindra and Rawlings, 1997).

Fertility of fall-born ewe lambs bred during anestrus using ram introduction alone has not been successful; only $11 \%$ of fall-born ewe lambs were bred during the anestrous period in a group that was selected for spring breeding (Al-Shorepy and Notter, 1996). Knights et al. (2002) investigated the ability of ram introduction to induce LH secretion, estrus, and ovulation in fall-born ewe lambs during July of the anestrous period. The experimental groups were no treatment; introduced to ram; treated with progesterone (via a CIDR) for five days; treated with CIDR for five days and introduced to rams at CIDR removal; and treated with CIDR for five days, introduced to rams at CIDR removal, and injected with estradiol benzoate 24 hours after CIDR removal. Lambs that were exposed to rams showed an LH surge, while those not exposed to rams did not.

Testosterone-treated wethers were introduced to a group of Merino ewes (post-partum day 15 to 43) that lambed in the autumn, and ovulation was induced within four days but was not accompanied by estrus (Geytenbeek et al., 1984). However, the overall proportion of ewes that showed estrus in the presence of the wethers by post-partum day 82 was similar despite the post-partum interval, indicating 
that the time of ram introduction during the post-partum interval is not indicative of whether the ewe will exhibit estrus or not. In another study performed during the non-breeding season, post-partum Corriedale ewes and ewes that lambed several months previously responded equally to the ram effect with a similar number of ewes showing estrus (Ungerfeld et al., 2002). However, in agreement with Wright et al. (1990), the conception rate was lower in the post-partum ewes, possibly as a consequence of suckling and low body condition scores.

In ewes that lambed during the non-breeding season, Khaldi (1984) reported that the percentage of ewes that ovulated after the introduction of rams was higher at 75 days than at 15, 30, 45, or 60 days after parturition. Similarly, Ungerfeld et al. (2004) did not find significant differences in estrous responses of anestrous, suckling Corriedale ewes after introducing rams at 5, 6, 7, or 8 weeks after parturition. However, conception rates in ewes induced to cycle 7 to 8 weeks after lambing were higher than in ewes induced to cycle 5 to 6 weeks after lambing (37.5\% vs. 5.9\%) (Silva and Ungerfeld, unpublished observations).

Reproductive responses of seasonally anestrous suckling Corriedale ewes to the ram effect were studied (Silva and Ungerfeld, 2006). The authors found no significant differences in the frequency of estrus between suckled and weaned ewes (85.3 vs. 93.2\%) exposed to rams. However, the overall conception rate was significantly higher in ewes that were weaned at least six months before the study started than in 60 to 90 days post-partum ewes that were suckling (63.6 vs. $45.3 \%$ ). Although the ram effect could be used to induce estrus during post-partum, fertility responses were low, presumably due to lactation and body condition of ewes. The authors suggested that low fertility in early post-partum anestrous ewes could be a result of low ovulation rate or induced ovulation of premature/aged follicles.

Inducing a fertile estrus in anestrous ewes using ram introduction alone has proven effective; however, the fertility responses may be poor (Al-Shorepy and Notter, 1996; Ungerfeld et al., 2002; and 
Silva and Ungerfeld, 2006) compared to animals bred in season. Responses to the ram effect vary and are affected by both ram- and ewe-associated factors (reviewed by Knights et al., 2004). Therefore, ram introduction alone is not adequate for breeding ewes outside their normal breeding season. Fertility of ewes bred out-of-season can be enhanced by pre-treatment with progesterone prior to the introduction of rams (Knights et al., 2004).

\section{B. Progestogen Pre-Treatments}

Treatment with progesterone or other progestogens prior to ram introduction has been used to induce estrus in ewes bred during the non-breeding season. The effectiveness of various delivery systems and types of progestogens was reviewed by Knights et al. (2004). There are four methods of progesterone delivery orally, via injection, via implant, or intravaginally.

Melengestrol acetate (MGA), a commercially available synthetic progestogen, is orally active in ruminants and, compared with other orally active progestogens, MGA is the most potent (Zimbelman, 1963). Several studies have been conducted to evaluate the use of MGA-based treatments to induce and synchronize estrous activity in seasonally anestrous ewes (Safranski et al., 1992; Umberger and Lewis, 1992; Jabbar et al., 1994; and Powell et al., 1996). MGA alone was associated with poor estrous synchronization responses as compared with the use of MGA in combination with an estrogen-like compound, zeranol (Powell et al., 1996). In addition, Jabbar et al. (1994) found no significant difference in estrous responses between MGA-treated ewes and controls ewes. However, Safranski et al. (1992) reported an increase in estrous responses in MGA-treated animals compared to controls. Treatment of anestrous ewes with MGA elicits varying degrees of estrous synchronization and, thus, is not an ideal product to use for synchronizing estrus in seasonally anestrous ewes.

A series of studies was conducted to evaluate the effects of three different progesterone delivery methods on improving fertility in ewes bred outside their normal breeding season (Daniel et al. 
2001). In the first experiment, ewes were randomly assigned to receive (a) the control diet for eight days (C), (b) the control diet with MGA added for eight days (MGA8), (c) the control diet with MGA added on day 7.5 (MGA1), or (d) the control diet with plus an injection of progesterone on day eight (P). The group reported that ewes in the MGA8 and $\mathrm{P}$ treated groups had higher lambing rates and a greater percentage from those groups lambed compared to the MGA1 and C groups. In experiment 2, treatment groups $C$ and MGA8 remained the same, while the last group was fed a control diet and given a CIDR for eight days (CIDR group). Both MGA8 and CIDR groups exhibited estrus earlier than controls, and a greater percentage of ewes lambed in those groups compared to the control group. Collectively, these data led to the conclusion that all three methods of progesterone delivery were successful in improving fertility in anestrous ewes, although to different degrees.

Delivery of progesterone intravaginally might be more effective in synchronizing estrus in anovular ewes. Progesterone-impregnated sponges, implants, and CIDRs have been used as reproductive management tools to effectively synchronize estrus (Welch et al., 1984; Welch, 1985a; Welch, 1985b; Hamra et al., 1986; Hamra et al., 1989; and Wheaton et al., 1992). Ewes pre-treated with progesterone via CIDRs exhibit estrus sooner and in a more synchronized manner than those treated with sponges (Welch et al., 1984; and Welch, 1985b) or oral MGA treatment (Daniel et al., 2001). In addition, the retention rate of CIDRs was similar to sponges; however, sponges tended to get stuck in the vaginal constriction, whereas CIDRS did not (Welch, 1985b).

The effective dose of exogenous progesterone embedded on sponges was evaluated in anestrous ewes (Mac Donnell and Crowley, 1978). A similar quantity of progesterone (250 mg) was absorbed by ewes regardless of the dose administered (between $500 \mathrm{mg}$ and $1200 \mathrm{mg}$ ). Fertility appears to be regulated by adequate absorption of progesterone at different thresholds. As suggested by the authors, the first dose of a given progesterone treatment must be sufficient to inhibit ovulation, the 
second to condition the ewe for estrus, and the third to ensure full fertility. Adequate absorption of progesterone through the vaginal wall is essential to elicit fertility.

Plasma concentrations of progesterone were measured to compare efficacy of progesterone delivery devices. Hamra et al. (1986) compared the plasma progesterone in ovariectomized ewes treated with CIDRs ( $9 \%$ vs. $12 \%$ ), sponges, and implants. The two types of CIDRs produced similar mean progesterone concentrations during the treatment period, and those concentrations were about two times those obtained with the implants and sponges.

When treated with CIDR devices, the interval from CIDR removal to expression of estrus can vary between 24 and 80 hours. When Perendale ewes were treated with CIDR devices to synchronize estrus for artificial insemination, the majority of ewes (49\%) expressed estrus between 48 to 54 hours after device removal; $16 \%$ expressed estrus between 24 to 36 hours afterwards, $24 \%$ between 72 to 80 hours, and $10 \%$ were not detected in estrus (Welch, 1985a).

Hamra et al. (1989) compared the efficacy of progesterone sponges, cronolone sponges (same as flurogestone acetate), and CIDRs in seasonally anestrous ewes and concluded that CIDRs can effectively be used in place of cronolone or other progestogen sponges to induce estrus. Sponges also can be impregnated with medroxyprogesterone acetate (MAP; Veramix). However, estrous responses and overall fertility varied greatly with intravaginal sponges (Wildeus, 2000).

Wheaton et al. (1992) examined the effects of using exogenous progesterone (via CIDRs) in combination with the ram effect as part of an accelerated lambing program. Two experiments were conducted to determine whether CIDRs could be used in conjunction with the ram effect to advance both the onset of the breeding season and lambing in seasonally anestrous ewes in late summer and in mid-spring. In the first experiment, Finn crossbred and Columbia ewes were either treated with CIDRs for 12 days or used as controls in July and again the following March. The intervals from CIDR 
removal/ram introduction to first estrus and to lambing were significantly shorter in CIDR-treated ewes as compared to the controls. In the second experiment, Finn crossbred, Columbia and Polypay ewes were either treated with CIDRs for 12 days or used as controls in April. Again, the intervals from CIDR removal/ram introduction to first estrus and to lambing were significantly shorter in CIDR-treated ewes as compared to the controls. These studies demonstrate the potential benefits of using CIDRs, followed by ram introduction, when breeding seasonally anestrous ewes as part of an accelerated breeding program.

A series of studies was conducted to determine the effectiveness of intravaginal progesterone inserts (polycapralactone) in combination with FSH to increase fertility responses in anestrous ewes (Knights et al., 2001a,b). In the first experiment, ewes were assigned randomly to one of four groups: untreated controls (C); progesterone for 12 days (P12), progesterone for 12 days with FSH (P12F); or progesterone for five days with FSH (P5F). Estrous responses were greater in the progesterone-treated groups (ranging from 66 to 79\%) than in the control group (12\%) and in P5F compared to P12F (79 vs. $66 \%$ ). More progesterone-treated ewes lambed to the first (from 38 to 45 vs. $0 \%$ ) or both (from 63 to 66 vs. $41 \%$ ) service periods compared to controls ewes. The authors concluded that an effective protocol to induce synchronized estrus and ovulation in anestrous ewes was a five-day treatment with an intravaginal progesterone insert in combination with ram introduction at insert removal. However, the use of polycapralactone inserts was discontinued because progesterone delivery was lower than would be required to synchronize estrus in ewes during the non-breeding season.

Knights et al. (2001b) evaluated the effectiveness of a five-day CIDR to induce a fertile estrus and the ability of FSH given one day before CIDR removal to increase ovulation rate and prolificacy in anestrous ewes. Estrous responses were higher in CIDR-treated ewes than in control ewes (77 vs. 20\%), but did not differ between FSH-treated and non-treated groups. Conception (68\%) and pregnancy (52\%) 
rates were higher in CIDR-treated ewes than in control ewes (0\%) ewes. In addition, neither the ovulation rate nor prolificacy to first service or overall differed due to $\mathrm{FSH}$. A five-day CIDR with ram introduction was sufficient to induce estrous and increase reproductive successes in anestrous ewes.

Progesterone pre-treatment plays an important role in lifespan of the developing corpora lutea. Pearce et al. (1985) demonstrated that progesterone administration immediately prior to the introduction of rams prevented the untimely regression of the corpus luteum in $100 \%$ of the treated animals that ovulated in response to the ram. Progesterone priming of ewes bred during the anestrous period increased estrous activity and mating at the synchronized ovulation and prevented premature regression of corpora lutea in ewes responding to the ram (Jabbar et al., 1994). Collectively, these data demonstrated the ability of progesterone pre-treatment delivered via a CIDR device to induce a fertile estrus in ewes bred during the anestrous season.

\section{Use of Gonadotropin Co-treatments in Ewes Bred Out-of-Season}

Luteinizing hormone (LH) and follicle stimulating hormone (FSH) are gonadotropins that are routinely incorporated into estrous induction protocols, in combination with progesterone pretreatments, to induce fertile estrus in ewes bred outside their normal breeding season (Wildeus, 2000). Both LH and FSH are secreted naturally from the anterior pituitary in response to an increase in gonadotropin-releasing hormone $(\mathrm{GnRH})$ and act at the level of the ovary. FSH stimulates the recruitment of immature follicles, and growth and maturation of growing follicles, while LH stimulates maturation of follicles, ovulation of ova from mature follicles, and formation of the corpus luteum from the residual cells of the follicle (Senger, 2003). However, because ewes in anestrus show a reduced secretion of $\mathrm{LH}$ and FSH, final stage of maturation of follicles and ovulation are not seen. Thus, using exogenous gonadotropins in estrous induction protocols could potentially supplement the ram-induced secretion of the gonadotropins, resulting in increased fertility in anestrous ewes. 
Equine chorionic gonadotropin (eCG) mimics the action of $\mathrm{FSH}$ in non-equids and has been investigated as part of an estrous induction protocol for anestrous ewes. However, its long-acting biological activity can cause the continual recruitment of antral follicles, resulting in a large number of non-ovulated follicles (Armstrong et al., 1983). Several studies have examined the dose response to eCG (Ainsworth and Shrestha, 1985; Smith et al., 1988; Knight et al., 1989; Zonturlu et al., 2001) and its effects on fertility of anestrous ewes (Zarkawi et al, 1999; Zeleke et al., 2005).

The effect of dose of eCG on the fertility of ewes bred in May and January after treatment with progestogen sponges and eCG (250 IU or $500 \mathrm{IU})$ was evaluated by Ainsworth and Shrestha (1985). The overall reproductive performance of the ewes was similar at the two breeding periods. Dosage of eCG had no significant effect on fertility. There was no advantage of using a higher dose of eCG when synchronizing estrus in ewes bred in-season or out-of-season. Likewise, Knight et al. (1989) observed no significant improvement in fertility responses as eCG dose was increased from 350 IU to 500 IU in Romney ewes bred out-of-season in New Zealand.

Smith et al. (1988) examined the effects of CIDRs and eCG (0,400, and $800 \mathrm{IU})$ on estrous response, ovulation, and conception rate in Coopworth ewes bred outside the normal breeding season in New Zealand. The interval from CIDR removal to the expression of estrus and the duration of estrus were longer in the eCG-treated ewes as compared to the controls, while the ovulation rate increased with dose of eCG. However, conception rate declined in eCG-treated ewes. Despite the ability of progesterone pre-treatment in combination with eCG to induce breeding activity year-round in seasonal breeds in New Zealand, Smith et al. (1988) pointed out that a seasonal pattern in fertility still existed in ewes.

Zonturlu et al. (2011) evaluated different doses of eCG on estrous synchronization and fertility in Awassi ewes that were treated with progesterone sponges during the transition period. Doses were 0 
IU, $300 \mathrm{IU}, 400 \mathrm{IU}$, and $500 \mathrm{IU}$. Estrous responses, pregnancy rates, and lambing rates were similar among all groups. The different doses of eCG used in this study in combination with progesterone pretreatment had similar effects on estrous synchronization and fertility, and the values were not different than control ewes.

Barrett et al. (2004) evaluated the effect of a single dose of 500 IU of eCG following a 12-day treatment with progestogen-releasing intravaginal sponges on ovarian responses in anestrous ewes. All eCG-treated ewes ovulated, while only one of six control ewes ovulated. Ovulatory-sized follicles were more estrogenic in eCG-treated ewes, leading to the consistent occurrence of estrus and ovulation.

The effect of intravaginal progesterone sponges in combination with eCG on inducing synchronized estrus and improving fertility was evaluated in anestrous, Awassi ewes by Zarkawi et al. (1999). Ewes were treated with intravaginal progesterone sponges for 14 days and received either an injection of $400 \mathrm{IU}$ of eCG at sponge removal or no further treatment. Ewes treated with eCG had significantly higher estrous responses (96 vs. $33 \%$ ), lambing rates ( 80 vs. $33 \%$ ), and overall fecundity (138 vs. 107\%) as compared to control ewes. The authors concluded that eCG in combination with progesterone pre-treatment was sufficient to induce synchronized estrus and improve fertility in anestrous ewes.

In another study (Zeleke et al., 2005) examined effects of progesterone and eCG on fertility in ewes during the transition period. This group used two different progestogens, MAP and FGA, and two routes of eCG administration, subcutaneously and intramuscularly, at three different times (24 hours prior to, at, and 24 hours after sponge removal) to compare synchronization efficiency and fertility following artificial insemination. There were no significant differences in estrous responses, time to estrus, and the duration of the induced estrus between types of progestogens used or time and route of administration of eCG. However, ewes that received 300 IU of eCG 24 hours prior to or at sponge 
removal had significantly higher pregnancy, lambing, and fecundity rates as compared to the control ewes. In addition, the subcutaneous route of administration resulted in higher fertility rates compared to intramuscularly.

The pattern of follicular growth and ovulation was examined in anestrous ewes treated with progestogen and eCG by Leyva et al. (1998). Ewes were either untreated, treated with progestogen sponges for 12 days followed by 750 IU eCG at sponge removal, or eCG alone. All animals, including untreated control ewes, exhibited waves of follicular activity. Ewes treated with eCG alone ovulated, but experienced short luteal phases attributed either to persistence of large follicles after ovulation or the lack of progesterone pre-treatment. Ewes treated with progestogen and eCG had increased growth of the largest follicle due to a delay in ovulation and the LH surge, an increased number of follicles that responded to eCG treatment, an increased ovulation rate through recruitment of ovulatory follicles, and delayed growth of large follicles after ovulation, which allowed for progesterone to rise to sufficient levels for normal luteal function.

For ewes bred outside their normal breeding season, estrous induction and synchronization protocols that combine progesterone pre-treatment with eCG have proven to be effective. However, fertility rates are lower than those observed in ewes bred in-season. One theory for the lower fertility rates observed in ewes bred out-of-season is the lack of an LH-like effect. For example, while FSH stimulates growth and maturation of the follicles on the ovary, without the necessary effects of LH to cause ovulation of ova from the mature follicles, prolonged persistence of large follicles could occur. LH has been shown to have an effect on the maturation of follicles in anestrous ewes (McNatty et al., 1981). Subsequently, a requirement for a minimum amount of LH for ovulation to occur in ewes bred out-of-season has been reported (Chupin et al., 1987). Furthermore, the ratio of FSH/LH is important in 
ovarian stimulation (Moor et al., 1984). Collectively, these data indicate that both FSH-like and LH-like effects are necessary for optimum fertility responses in ewes bred out-of-season.

P.G. $600^{\circledR}$ is mixture of gonadotropins with FSH-like and LH-like activity and contains 400 IU eCG and $200 \mathrm{IU}$ hCG per $5 \mathrm{~mL}$ dose. It is approved for and generally recommended for inducing a fertile estrus in pre-pubertal gilts (Britt et al., 1989) or as part of an estrous synchronization program in sows (Knox et al., 2001). However, its potential benefits in improving fertility and fecundity in ewes bred outside their normal breeding season have not been thoroughly evaluated.

P.G. $600^{\circledast}$ can be used in place of other exogenous hormones in estrous induction protocols to prepare ewes for natural breeding. A few groups have studied the effects of P.G. $600^{\circledR}$ in combination with the orally active progestogen, MGA (Safranski et al., 1992; Jabbar et al., 1994; Windorski et al., 2008). Ewes treated with $5 \mathrm{~mL}$ of P.G. $600^{\circledR}$ following pre-treatment with MGA had a higher ovulation rate than control ewes and the effect was enhanced by MGA, whereas treatment with MGA alone tended to decrease ovulation rate (Safranski et al., 1992). MGA-treated ewes also showed a higher percentage of ewes lambing and number of lambs born per ewe exposed, but these effects were not improved by treatment with P.G. $600^{\circledR}$ (Safranski et al., 1992).

Another study was conducted to examine the use of two different commercially available progestogen products, MGA and norgestomet [Synchro-Mate-B (SMB), Sanofi Animal Health, Overland Park, KS], used with and without P.G. $600^{\circledR}\left(5 \mathrm{~mL}\right.$ ) or zeranol (Ralgro ${ }^{\circledR}, 2.5 \mathrm{mg}$, Pitman-Moore, Terre Haute, IN), which is a commercially available growth promotant for cattle and sheep, to induce synchronized estrus in anestrous ewes (Jabbar et al., 1994). Mating at synchronized estrus was greater for progestogen-treated ewes. However, no differences were observed in estrous responses in response to P.G. $600^{\circledR}$ or zeranol treatments. Progestogen-treated ewes lambed sooner than non-treated controls. Ewes receiving zeranol had similar fertility responses to those of ewes receiving P.G. $600^{\circledR}$ after 
progestogen treatment. P.G. $600^{\circledR}$, in combination with progestogen treatment, did not enhance the fertility of ewes beyond that attained using zeranol.

Windorski et al. (2008) evaluated the effects of MGA and P.G. $600^{\circledR}(5 \mathrm{~mL})$ on fertility in ewes bred outside of the normal breeding season. Treatment with MGA increased the percentage of ewes that mated and conceived during the first six days of the breeding period and reduced the interval to lambing compared to both treatment with P.G. $600^{\circledR}$ alone and no treatment. Treatment with MGA in combination with P.G. $600^{\circledR}$ increased the number of luteal structures present on the ovary early during the breeding period but did not significantly improve ewe prolificacy.

A study was conducted in two replicates to determine the effects of eCG (400 IU) and P.G. $600^{\circledR}$ $(5 \mathrm{~mL})$ on the timing of estrus and ovulation after progestogen withdrawal to prepare ewes for artificial insemination (Al; Cline et al., 2001). The interval from progestogen withdrawal to estrus was less in the eCG-treated group than in either the P.G. $600^{\circledR}$-treated or the control groups. The interval from implant removal to ovulation was greatest in the control group, and not different between the eCG- and P.G. $600^{\circledR}$-treated groups. The intervals from progesterone withdrawal to both estrus and ovulation were less consistent between replicates for the P.G. $600^{\circledR}$-treated group than for the eCG-treated group. To prepare anestrous ewes for Al during a pre-determined interval, eCG was a better choice than P.G. $600^{\circledR}$ as the gonadotropin to use at implant removal because eCG seemed to increase the predictability of intervals from implant removal to estrus and ovulation.

It is important to note that in previous studies that examined the effects of P.G. $600^{\circledR}$ on fertility in anestrous ewes, the number of animals used for the each treatment group was small (less than 40), which could contribute to the lack of effect observed for P.G. $600^{\circledR}$ (Safranski et al., 1992 and Jabbar et al., 1994). In addition, different effects were observed with different progestogen treatments. For example, the effect of P.G. $600^{\circledR}$ on ovulation rate was enhanced with the use of MGA (Safranski et al., 
1992), but fertility was not affected when P.G. $600^{\circledR}$ was used in combination with zeranol and MGA or SMB. Also, the effect of P.G. $600^{\circledR}$ on lambing rate was enhanced by the use of SMB as the source of progesterone pre-treatment compared with MGA (Jabbar et al., 1994). It appears that the effects of P.G. $600^{\circledR}$ could be related to the method of progestogen pre-treatment.

P.G. $600^{\circledR}$ acted at the level of the ovary to increase the recruitment and growth of follicles and subsequent ovulation of the follicles (Windorski et al., 2008). As follicles grow, they begin to produce estradiol and another hormone, inhibin, which decreases FSH secretion from the anterior pituitary. As inhibin concentration increases with follicular growth, so too does the degree of negative feedback on the pituitary. As a result, FSH secretion declines and stays low due to the increased estradiol and inhibin. The drop in FSH is believed to cause other growing follicles to become atretic and die (Senger, 2003), potentially leading to lower fertility caused by lack of ovulable follicles. To keep estradiol levels from becoming too high and possibly causing lower fertility in ewes bred during the anestrous period, the dose of P.G. $600^{\circledR}$ in the estrous induction protocol can be lowered.

Studies that have used P.G. $600^{\circledR}$ in combination with progestogen pre-treatment in attempts to increase fertility in anestrous ewes have reported using the full $5 \mathrm{~mL}$ porcine dose (Safranski et al., 1992; Jabbar et al., 1994; Cline et al., 2001; and Windorski et al., 2008). If the full dose of P.G. $600^{\circledR}$ is administered to anestrous ewes, it is likely that estradiol concentrations would be higher than if only a portion of the full dose was administered. Thus, a $3 \mathrm{~mL}$ dose of P.G. $600^{\circledR}$ was used in combination with progesterone pre-treatment and ram introduction to determine its effects on reproductive successes in non-lactating ewes bred during the anestrous period. 


\section{STATEMENT OF THE PROBLEM}

Attempts to breed ewes out-of-season have relied primarily on ram introduction alone or progesterone pre-treatment prior to the introduction of rams. However, the response of anestrous ewes to ram introduction alone or in combination with progesterone pre-treatment can be low and variable. A more moderate and consistent fertility response has been observed using progesterone pretreatment delivered via a CIDR device. However, fertility from these treatments still remains below that observed in ewes during the breeding season. Using exogenous gonadotropins in estrous induction protocols could have beneficial effects when breeding ewes during anestrus.

The use of various gonadotropins as part of estrous induction protocols has been evaluated. Few of these gonadotropins are commercially available for use in livestock. P.G. $600^{\circledR}$ is a commercially available gonadotropin mixture for use in swine. Few studies have evaluated the effectiveness of P.G. $600^{\circledR}$ in inducing a fertile estrus in sheep. These studies generally used a small number of animals and have found little effect of P.G. $600^{\circledR}$. Additionally, the effect of the gonadotropins might vary with the type of progestogen used in pre-treatment. No studies on the use of P.G. $600^{\circledR}$ in combination with progesterone pre-treatment delivered via a CIDR device have been reported. Given that the CIDR is the only approved progestogen delivery system approved for sheep in the U.S., it was deemed appropriate to examine whether use of the gonadotropin mixture could enhance response to the device.

In an attempt to increase fertility and overall reproductive successes in anestrous ewes, a mixture of gonadotropins, P.G. $600^{\circledR}$ [3 mL (240 IU eCG, 120 IU hCG)], was used in combination with ram introduction and progesterone pre-treatment via a CIDR device. It was hypothesized that giving a $3 \mathrm{~mL}$ dose of P.G. $600^{\circledR}$ at or one day prior to CIDR insert removal would increase reproductive successes in ewes bred outside the normal breeding season. 


\section{INTRODUCTION}

Seasonal reproduction of sheep limits the natural breeding season to the short days of fall and early winter and has framed the conventional management system of breeding ewes in the fall, with subsequent lambing occurring in the spring. The traditional fall-breeding, spring-lambing production system exposes producers to increased financial and marketing risks associated with seasonally low prices. Producers practicing traditional breeding systems experience increased production risks of higher lamb mortality and morbidity associated with lambs grazing pastures in spring and summer, when predation and parasitism are highest. Further, the traditional lamb production system limits productivity to one lamb crop annually (Singh-Knights, 2003).

In contrast, breeding ewes outside the normal breeding season could allow producers to not only take advantage of higher lamb prices, but also enhance the productivity of ewes by placing them in an accelerated breeding program. Additionally, shifting to an out-of-season breeding (OSB) system would help mitigate the production risk of animal mortality due to predation and parasites, as lambs would be born in the winter months, and as demonstrated by Singh-Knights (2003), loss due to predation is lessened during the fall months. Thus, OSB can help producers survive in an industry that is increasingly competitive and risky.

To breed anestrous ewes, estrus must first be induced. A number of estrous induction protocols exist. Recently, an approach involving progesterone pre-treatment via a CIDR device prior to ram introduction was shown to be effective in inducing a fertile, synchronized estrus in ewes exposed during the anestrous period (Knights et al., 2001a,b). Moreover, the CIDR device is the only U.S. FDA approved method of delivering progesterone for synchronization of estrus in sheep. However, fertility of ewes bred during the non-breeding season using this approach is lower and more variable than when ewes are bred during the normal breeding season. 
Using exogenous gonadotropins as part of an estrous induction protocol can have beneficial effects on fertility in ewes bred out-of-season. P.G. $600^{\circledR}$ is a combination of eCG and hCG, with FSH-like and LH-like activity, and is approved for inducing a fertile estrus in swine. Few studies have evaluated the ability of P.G. $600^{\circledR}$ to increase fertility in ewes bred during the anestrous period and, in particular, following the pre-treatment with progesterone delivered via CIDR devices. Therefore, the objective of this study was to determine the effects of P.G. $600^{\circledR}$ administered at or one day prior to CIDR removal on reproductive successes in non-lactating ewes bred during the anestrous period. 


\section{MATERIALS AND METHODS}

\section{Farms and Animals}

This study was conducted during the spring and summers of 2011 (experiment 1) and 2012 (experiment 2) on six farms located in West Virginia and southwestern Pennsylvania. The location of farms, breed of animals, and number of animals used in the study are in Table 1 . The ewes $(n=831)$ ranged from two to five years old. All animals were managed on mixed grass legume pastures and were allowed ad libitum access to water and shade.

Table 1. Location, breed, and number of animals used for Experiments 1 and 2

\begin{tabular}{|c|l|c|c|c|c|c|}
\hline \multirow{2}{*}{ Farm } & \multirow{2}{*}{ Location } & \multirow{2}{*}{ Breed } & \multicolumn{2}{|c|}{$\begin{array}{c}\text { Experiment 1 } \\
\text { (N per group) }\end{array}$} & \multicolumn{2}{|c|}{$\begin{array}{c}\text { Experiment 2 } \\
\text { (N per group) }\end{array}$} \\
\cline { 5 - 7 } & & Control & Treated & Control & Treated \\
\hline $\mathbf{1}$ & Harrisville, WV (Richie County) & Katahdin & - & - & 33 & 42 \\
\hline $\mathbf{2}$ & Osceola, WV (Randolph County) & Suffolk & 70 & 73 & 58 & 42 \\
\hline $\mathbf{3}$ & Whitmer, WV (Randolph County) & Suffolk & - & - & 39 & 41 \\
\hline $\mathbf{4}$ & Scenery Hill, PA (Washington County) & Dorset/Texel & 51 & 50 & 57 & 56 \\
\hline $\mathbf{5}$ & Aurora, WV (Preston County) & Dorset & 30 & 35 & 41 & 53 \\
\hline $\mathbf{6}$ & Wardensville, WV (Hardy County) & Katahdin & - & - & 37 & 23 \\
\hline
\end{tabular}

\section{Treatments}

All procedures were approved by the West Virginia University Animal Care and Use Committee.

\section{Experiment 1}

To evaluate the effect of P.G. $600^{\circledR}$ on fertility of ewes exposed to rams during the non-breeding season, non-lactating ewes of mixed breeds $(n=309)$ on three farms and separated from rams for at least one month prior to the beginning of the experiment, received a controlled internal drug releasing (CIDR) device (containing 300 mg of progesterone; InterAg; Hamilton, New Zealand) for five days (during May through July of 2011) prior to ram introduction (RI). At farm 2, 28 controls and 34 treated ewes 
were synchronized twelve days prior to the remaining 42 controls and 39 treated ewes due to the producer's management schedule. At CIDR removal, ewes were assigned randomly to receive either an injection of P.G. $600^{\circledR}$ [3 mL, i.m. (240 IU eCG, 120 IU hCG), Intervet, Millsboro, DE] or no further treatment and were joined with a group of sexually mature rams at a ratio not less than one ram per 25 ewes.

Experiment 2

Experiment 2 was conducted during April through July of 2012 and was similar to Experiment 1 except that P.G. $600^{\circledR}$ was given one day prior to CIDR removal instead of at CIDR removal and three additional farms were used for the second experiment $(N=522$, Table 1). At farm 5, 23 controls and 24 treated ewes were synchronized on 26 April, 9 controls and 8 treated ewes on 1 May, and 9 controls and 21 treated ewes on 25 June to fit the producer's management schedule.

\section{Estrous Detection}

Rams fitted with marking harnesses were joined with ewes for approximately 40 days beginning at CIDR removal. To detect estrus, ewes were observed for the presence of raddle marks during 24 through 96 hours after ram introduction. Estrous responses were collected from two of three farms in experiment 1 and four of six farms in experiment 2. Responses were not collected from some farms because it was not convenient for the producers to gather their animals after the initial treatments.

\section{Pregnancy Diagnosis and Lambing Data}

Pregnancy diagnosis was conducted between 30 and 35 days after ram introduction to determine pregnancy to the first service and again between 50 and 55 days after ram introduction to determine pregnancy to the second service. Ewes were scanned via trans-rectal ultrasonography using an Aloka 500 (Corometrics Medical Systems, Wallingford, CT, USA) with a 7.5-mHz, linear trans-rectal 
probe. In experiment 1, pregnancy checks to both first and second services were conducted on two of three farms. In experiment 2, pregnancy checks to first service were conducted at all six farms, while pregnancy to second service was conducted on four of six farms. Pregnancy checks were not conducted on certain farms due to logistical problems (i.e. locating animals on very large, wooded pastures and the absence of handling facilities). Lambing records were collected from all farms except one in experiment 1. The farm at which lambing records were not collected experienced significant loss of animals due to predation, and the producer did not distinguish between animals that died and those that did not lamb.

\section{Statistical Analysis}

Analysis of variance (ANOVA) was conducted using the GLM procedure of SAS (SAS Inst. Inc., Cary, NC) to determine the effect of treatment with P.G. $600^{\circledR}$ on the reproductive performance of progesterone pre-treated, non-lactating ewes during the non-breeding season. The fixed effects included treatment (with or without P.G. $600^{\circledR}$ ), farm, and their interaction; response variables included prolificacy (number of lambs born per ewe lambing), the interval from ram introduction to lambing, the mean lambing day (day that ewe lambed during the lambing period) and lambing rates (lambs born per ewe exposed). The effects of treatment on the proportion of ewes that showed estrus, pregnancy and conception rates, proportion of ewes lambing to the first service period (ewes lambing by day 13 of the lambing period) and overall, and pregnancy retention to the first and second services (ewes that lambed that were pregnant to the first and second services, respectively) were evaluated by Chi-square using the PROC FREQ procedure of SAS. 


\section{RESULTS}

\section{Experiment 1}

The mean values of reproductive variables for control and P.G. $600^{\circledR}$-treated ewes are presented in Table 2. Ewes treated with P.G. $600^{\circledR}$ had higher estrous responses than non-treated control ewes $(P=$ $0.01 ; 79.2$ vs. 94.2 , respectively; Table 2 ). Prolificacy also tended to be higher in P.G. $600^{\circledR}$-treated ewes than in control ewes ( $P=0.06 ; 1.67$ vs. 1.47 , respectively; Table 2$)$. There was no effect of treatment on the other reproductive performance variables (Table 2).

Table 2. Effects of P.G. $600^{\circledR}$ administered at CIDR removal on reproductive responses in non-lactating ewes treated with a CIDR 5 days prior to ram introduction during the anestrous period.

\begin{tabular}{|c|c|c|c|}
\hline \multirow[b]{2}{*}{ Variable } & \multicolumn{2}{|c|}{ Treatment } & \multirow[b]{2}{*}{ P-value } \\
\hline & Control & P.G. $600^{\circledR}$ & \\
\hline Estrous response $(\%)^{a}$ & $79.2 \pm 4.3(n=58)$ & $94.2 \pm 3.9(n=69)$ & $P=0.01$ \\
\hline Conception rate $(\%)^{b}$ & $48.5 \pm 7.6(n=45)$ & $55.6 \pm 6.4(n=63)$ & NS \\
\hline \multicolumn{4}{|l|}{ Pregnancy rate (\%) } \\
\hline $1^{\text {st }}$ service ${ }^{c}$ & $54.1 \pm 4.8(n=98)$ & $61.5 \pm 4.5(n=106)$ & NS \\
\hline $2^{\text {nd }}$ service $^{d}$ & $49.0 \pm 9.2(n=28)$ & $43.9 \pm 9.7(n=28)$ & NS \\
\hline Overall & $71.9 \pm 4.9(n=98)$ & $69.7 \pm 4.4(n=111)$ & NS \\
\hline Prolificacy $^{e}$ & $1.47 \pm 0.07(n=88)$ & $1.67 \pm 0.07(n=79)$ & $P=0.06$ \\
\hline Lambing to $1^{\text {st }}$ service (\%) & $47.5 \pm 4.6(n=123)$ & $48.2 \pm 4.5(n=124)$ & NS \\
\hline Ram introduction to lambing (d) & $154.4 \pm 1.2(n=53)$ & $153.2 \pm 1.3(n=50)$ & NS \\
\hline Lambing day $(d)^{f}$ & $10.0 \pm 1.0(n=88)$ & $7.98 \pm 1.1(n=79)$ & NS \\
\hline Pregnancy retention to $1^{\text {st }}$ service $(\%)^{g}$ & $85.5 \pm 6.0(n=48)$ & $82.5 \pm 5.9(n=47)$ & NS \\
\hline Pregnancy retention to $2^{\text {nd }}$ service (\%) ${ }^{h}$ & $84.5 \pm 4.7(n=62)$ & $89.0 \pm 5.0(n=55)$ & NS \\
\hline Lambed (\%) & $71.6 \pm 4.3(n=123)$ & $63.3 \pm 4.2(n=124)$ & NS \\
\hline Lambing rate $(\%)^{i}$ & $106.5 \pm 8.2(n=123)$ & $104.8 \pm 8.0(n=124)$ & NS \\
\hline \multicolumn{4}{|c|}{ Not all variables were measured for all animals. N's are indicated for each variable under treatment groups. } \\
\hline \multicolumn{4}{|c|}{${ }^{a}$ Number of ewes marked by rams of all ewes in a treatment group. } \\
\hline \multicolumn{4}{|c|}{${ }^{b}$ Number of ewes diagnosed pregnant as a percentage of ewes marked by rams. } \\
\hline \multicolumn{4}{|c|}{${ }^{c}$ Number of ewes diagnosed pregnant on day 30 to 35 as a percentage of all ewes exposed to rams. } \\
\hline \multicolumn{4}{|c|}{${ }^{d}$ Number of ewes diagnosed pregnant on day 50 to 55 expressed as a percentage of ewes not pregnant on day 30-35. } \\
\hline \multicolumn{4}{|c|}{ e Lambs born per ewe lambing. } \\
\hline \multicolumn{4}{|l|}{${ }^{f}$ Ewes lambing by day 13 of the lambing period. } \\
\hline \multicolumn{4}{|c|}{${ }^{g}$ Ewes lambing that were diagnosed pregnant to the first service. } \\
\hline \multicolumn{4}{|c|}{${ }^{h}$ Ewes lambing that were diagnosed pregnant to the second service. } \\
\hline \multicolumn{4}{|c|}{ 'Lambs born per ewe exposed. } \\
\hline Values are least squares means \pm SEM $(n$ & & & \\
\hline
\end{tabular}




\section{Experiment 2}

The mean values of reproductive variables for control and P.G. $600^{\circledR}$-treated ewes are presented in Table 3. Ewes treated with P.G. $600^{\circledR}$ had higher conceptions rates $(P=0.01 ; 51.8$ vs. 39.2, respectively; Table 3$)$, pregnancy rates to first service $(P=0.0007 ; 45.8$ vs. 32.0 , respectively; Table 3$)$, percentage of ewes lambing ( $P<0.0001 ; 61.2$ vs. 42.2 , respectively; Table 3$)$, and lambing rates $(P<$ $0.0001 ; 92.4$ vs. 63.6 , respectively; Table 3 ) compared to control ewes. There was no effect of treatment on the other reproductive performance variables (Table 3).

Table 3. Effects of P.G. $600^{\circledR}$ administered one day before CIDR removal on reproductive responses in non-lactating ewes treated with a CIDR 5 days prior to ram introduction during the anestrous period.

\begin{tabular}{|c|c|c|c|}
\hline \multirow[b]{2}{*}{ Variable } & \multicolumn{2}{|c|}{ Treatment } & \multirow[b]{2}{*}{ P-value } \\
\hline & Control & P.G. $600^{\circledR}$ & \\
\hline Estrous response (\%) ${ }^{a}$ & $79.6 \pm 2.4(n=245)$ & $84.3 \pm 2.4(n=243)$ & NS \\
\hline Conception rate $(\%)^{b}$ & $39.2 \pm 3.6(n=196)$ & $51.8 \pm 3.5(n=204)$ & $P=0.01$ \\
\hline \multicolumn{4}{|l|}{ Pregnancy rate (\%) } \\
\hline $1^{\text {st }}$ service $^{c}$ & $32.0 \pm 2.9(n=277)$ & $45.8 \pm 2.9(n=276)$ & $P=0.0007$ \\
\hline $2^{\text {nd }}$ service $^{d}$ & $34.3 \pm 4.3(n=109)$ & $37.0 \pm 4.7(n=100)$ & NS \\
\hline Overall & $51.7 \pm 3.2(n=193)$ & $59.9 \pm 3.3(n=197)$ & $P=0.07$ \\
\hline Prolificacy $^{e}$ & $1.45 \pm 0.10(n=129)$ & $1.51 \pm 0.05(n=173)$ & NS \\
\hline Lambing to $1^{\text {st }}$ service (\%) & $55.3 \pm 7.7(n=129)$ & $67.5 \pm 4.5(n=165)$ & NS \\
\hline Ram introduction to lambing (d) & $155.6 \pm 1.8(n=129)$ & $153.4 \pm 1.1(n=165)$ & NS \\
\hline Lambing day (d) ${ }^{f}$ & $13.3 \pm 1.8(n=129)$ & $10.9 \pm 1.1(n=165)$ & NS \\
\hline Pregnancy retention to $1^{\text {st }}$ service $(\%)^{g}$ & $88.5 \pm 32.1(n=87)$ & $90.7 \pm 29.2(n=118)$ & NS \\
\hline Pregnancy retention to $2^{\text {nd }}$ service $(\%)^{h}$ & $78.7 \pm 4.4(n=108)$ & $86.4 \pm 4.3(n=126)$ & NS \\
\hline Lambed (\%) & $42.2 \pm 2.7(n=273)$ & $61.2 \pm 2.7(n=268)$ & $P<0.0001$ \\
\hline 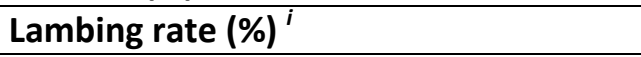 & $63.6 \pm 4.9(n=272)$ & $92.4 \pm 4.9(n=268)$ & $P<0.0001$ \\
\hline
\end{tabular}

Not all variables were measured for all animals. N's are indicated for each variable under treatment groups.

${ }^{a}$ Number of ewes marked by rams of all ewes in a treatment group.

${ }^{b}$ Number of ewes diagnosed pregnant as a percentage of ewes marked by rams.

${ }^{c}$ Number of ewes diagnosed pregnant on day 30 to 35 as a percentage of all ewes exposed to rams.

${ }^{d}$ Number of ewes diagnosed pregnant on day 50 to 55 expressed as a percentage of ewes not pregnant on day 30-35.

'Lambs born per ewe lambing.

${ }^{f}$ Ewes lambing by day 13 of the lambing period.

${ }^{g}$ Ewes lambing that were diagnosed pregnant to the first service.

${ }^{h}$ Ewes lambing that were diagnosed pregnant to the second service.

'Lambs born per ewe exposed..

Values are least squares means \pm SEM (number of animals). 
Economic Analysis of P.G. $600^{\circledR}$

Cost of treatment per 100 ewes

- Cost of P.G. $600^{\circledR}=\$ 43$ per bottle

- 1 bottle $=8$ injections

- $\quad 1$ injection $=\$ 5.38$

- Treatment of 100 ewes + supplies + labor $=\$ 600$

Additional revenue from fall-born ewe lambs

- $\quad 30$ additional lambs/100 ewes treated with P.G. $600^{\circledR}$

- $.75 \mathrm{c} / \mathrm{lb}$ profit for lambs $\times 30$ lambs $\times 100 \mathrm{lbs}=\$ 2,250$

Net benefit per 100 ewes

- $\$ 2,250-\$ 600=\$ 1,650$ 


\section{DISCUSSION}

Although previous studies have evaluated the effectiveness of P.G. $600^{\circledR}$ in combination with progestogen treatment in inducing and synchronizing estrus and enhancing fertility rates in ewes bred out-of-season (Safranski et al., 1992; Jabbar et al., 1994; Windorski et al., 2008), none of these reported the effects of a combination of eCG and hCG with progesterone delivered via CIDR devices. In addition, groups studying the effects of P.G. $600^{\circledR}$ in sheep have reported using the full porcine recommend dose (400 IU eCG and 200 IU hCG). In the present study, only 240 IU eCG and 120 IU hCG were administered to anestrous ewes in an attempt to increase reproductive success.

In experiment 1, estrous responses were higher in treated ewes compared to controls. This response is similar to Robinson and Smith (1967), who reported that administration of eCG following treatment with progesterone-impregnated sponges increased estrous responses in anestrous ewes, and Zarkawi et al. (1999), who found that ewes treated with $400 \mathrm{IU}$ of eCG following treatment with sponges containing $60 \mathrm{mg}$ of medroxyprogesterone acetate (MAP) had higher estrous responses compared to controls. Jabbar et al. (1994) also reported an increase in estrous responses of P.G. $600^{\circledR}$-treated ewes compared to controls.

In experiment 2, estrous responses were not different between treated animals and controls.

Presumably, allowing gonadotropin treatment additional time to facilitate growth and development of follicles would lead to an increased production of estrogen from the follicles, which would contribute to higher estrous responses, which was observed in Sirjani et al. (2011). However, that response was not observed in the current study.

The estrous responses for control ewes in the present study were similar to those previously reported by Knights et al. (2001b, 2003) for ewes that were treated with CIDR devices. Interestingly, the 
total percentages of ewes marked following a 10-day treatment with either MGA or SMB were 89 and 97\%, respectively (Jabbar et al., 1994). These differences could be a result of the different methods or duration of progestogen/progesterone pre-treatment. Additionally, there was a tendency for the magnitude of the difference between controls and treated animals to vary among farm in the present study.

Conception rates did not differ in experiment 1 , when gonadotropins were given at CIDR removal. Conversely, when P.G. $600^{\circledR}$ was administered one day prior to CIDR removal, conception rates were higher in treated ewes than in control ewes. However, Smith et al. (1988) observed a decline in conception rate in eCG-treated ewes bred out-of-season compared to controls. In that study, eCG (400 or 800 IU) was administered at CIDR removal. Evans and Armstrong (1983) reported that oocytes from eCG-treated females were associated with lower fertilization rates, which would result in lower conception rates. In addition, Moor et al. (1985) showed that, in developing oocytes, eCG induced changes in the pattern of synthesis of proteins that are associated with maturation in $28 \%$ of the treated oocytes compared to $6.5 \%$ and $0 \%$ in $\mathrm{FSH}$-treated and untreated oocytes, respectively. They found that estrogen secretion was more than doubled in follicles from eCG-treated and FSH-treated animals, another indication that the pattern of development of oocytes in animals treated with gonadotropins was modified. Disruption in the pattern of development could lead to ovulation of immature, aged, or even abnormal oocytes.

Doses of gonadotropins, which cause growth and development of different numbers of follicles, would be expected to cause different increases in estrogen production, as reported by Moor et al. (1985). Overtly high concentrations of estrogen could have negative effects on fertility, and specifically ovulation rates, by decreasing FSH production, which can cause other growing follicles to become atretic (Moor et al., 1984 and Senger, 2003). Additionally, in a study conducted in red deer, superovulation with 
eCG caused premature luteal regression caused by hypersecretion of estrogen, which triggered luteolysis (Bainbridge et al., 1998).

In addition to the effects of FSH, LH effects might be necessary for successful maturation and ovulation of the follicle. Devonish et al. (2009) observed that ovulation rate increased with decreasing concentrations of progesterone, likely caused by a greater LH pulse frequency. LH has been shown to have an effect on the maturation of follicles in ewes (McNatty et al., 1981 and Murdoch, 1985). A requirement for a minimum amount of LH for ovulation to occur in ewes bred out-of-season has been reported (Chupin et al., 1987). Specifically, LH receptors accumulate on the granulosal cells of the preovulatory follicle, which has become estrogenic, and will usually be the final step in maturation as the follicle prepares to respond to the pre-ovulatory LH surge (Richards, 1980 and Murdoch, 1985). Furthermore, Moor et al. (1984) reported on the importance of the ratio of FSH/LH in ovarian stimulation. A higher concentration of FSH and a lower concentration of $\mathrm{LH}$ resulted in the proper timing of oocyte activation. Prolonged exposure to high concentrations of LH lead to premature activation of oocytes and ovulation of aged eggs, which contributed to abnormal embryos (Moor et al., 1984). Collectively, these data indicate that both FSH-like and LH-like effects are necessary for optimum fertility responses in ewes bred out-of-season.

Pregnancy rates to the first service period were greater in P.G. $600^{\circledR}$-treated ewes compared to controls when gonadotropins were administered one day prior to CIDR removal, but not when given at CIDR removal. However, overall pregnancy rates were not different between treated ewes and control ewes, regardless of timing of P.G. $600^{\circledR}$ injection. Carpenter and Spitzer (1981) found that treatment of anestrous ewes with $750 \mathrm{IU}$ of eCG following norgestomet pre-treatment increased pregnancy rates to first service compared to ewes treated with norgestomet only. Zeleke et al. (2005) reported that ewes 
given 300 IU of eCG 24 hours prior to or at progestogen (60 mg MAP or 40 mg FGA) sponge removal had significantly higher pregnancy rates than ewes treated with sponges only.

Successful pregnancies are dependent upon successful estrus, conception, and, subsequently, implantation into the endometrium of the uterus. There are a few explanations as to why pregnancy rates to the first service period were greater in treated ewes, while no difference was observed in overall pregnancy rate between treated ewes and controls when P.G. $600^{\circledR}$ was administered one day prior to insert removal. Estrous responses were not different, but numerically higher, and conception rates were statistically higher in treated ewes than in controls, so one could speculate that pregnancy rates to the first service period would be higher, which was observed in the present study.

Embryonic and fetal losses have been studied in sheep (Hulet et al., 1956; Quinlivan, 1966; Schrick and Inskeep, 1993; and Dixon et al., 2007). Complete losses from day 18 to lambing were estimated at 9.4\% (Hulet et al., 1956), and late embryonic or fetal losses from day 30 to term were only from 1 to 5\% (Quinlivan, 1966). Dixon et al. (2007) reported that approximately $19.9 \%$ of ewes experienced late embryonic loss, fetal loss, or both, while $21.2 \%$ of the embryos or fetuses counted were lost from day 25 to term. Neither embryos nor fetuses were counted in the present study. However, it is possible that a portion of ewes experienced either partial or complete pregnancy loss, which could explain the differences observed in pregnancy to first service and overall pregnancy rate.

Pregnancy retention rates did not differ between first and second services in the current study, as was previously reported by Knights et al. (2001a, b). The question that still remains unanswered regarding pregnancy to the second service period in ewes bred out-of-season is are ewes not expressing estrus (i.e. continuing to cycle) or are they coming into heat, but the problem is related to conception or implantation? Further research needs to be conducted to address this issue. 
No difference in prolificacy was observed between treated ewes and controls when P.G. $600^{\circledR}$ was administered one day prior to CIDR removal. Conversely, when P.G. $600^{\circledR}$ was administered at CIDR removal, the number of lambs born per ewe lambing tended to be higher in treated ewes compared to controls. Windorski et al. (2008) reported that P.G. $600^{\circledR}$ increased the number of luteal structures present on the ovary, but neither the number of embryos nor the number of lambs born was significantly affected. Similarly, Safranski et al. (1992) reported ovulation rates of 1.39 and 2.30 for progestogen and progestogen plus P.G. $600^{\circledR}$-treated ewes, respectively, but prolificacy was not different between the treated ewes and the controls.

Prolificacy is related to ovulation rate, which could be affected by the half-lives of gonadotropins. For example, the chorionic gonadotropins have a significantly longer half-life than the pituitary gonadotropins (23 vs. 0.4 hours; Mock and Niswender, 1983), and as a result, there is a longer period of biological activity following treatment with chorionic gonadotropins. Thus, P.G. $600^{\circledR}$, which contains $200 \mathrm{IU}$ of hCG per $5 \mathrm{~mL}$ dose, could potentially cause premature ovulation of aged or immature oocytes (Moor et al., 1985) or luteinization of large hCG-responsive follicles without ovulation (Windorski et al., 2008); these two events could potentially contribute to higher counts of corpora lutea without increasing, or even lowering, prolificacy.

When P.G. $600^{\circledR}$ was administered one day prior to CIDR removal in the present study, a higher percentage of treated ewes lambed compared to controls. Similarly, Jabbar et al. (1994) reported that more P.G. $600^{\circledR}$-treated ewes lambed compared with SMB-only-treated ewes. This effect was not observed in ewes that were treated with MGA as the progestogen (Jabbar et al., 1994). Over $90 \%$ of the ewes in that study had lambed the previous fall, which could have contributed to the high overall percentage of ewes lambing. In the present study, more than $50 \%$ of all ewes lambed in late winter or 
early spring. As noted by Dunn and Kaltenbach (1980), length of the PPI influences fertility of ewes bred out-of-season.

An explanation for the higher percentage of treated ewes that lambed is that treatment with P.G. $600^{\circledR}$ one day prior to insert removal and ram introduction induced a more fertile estrus compared to the control ewes, which received no gonadotropin treatment. It has been documented that abrupt introduction of novel rams to anestrous ewes induced spontaneous ovulations, some of which were not associated with estrus (Oldham et al., 1978 and Martin et al., 1986). However, some ewes may never respond to the ram stimulus (Oldham et al., 1978). Therefore, the higher percentage of ewes lambing when P.G. $600^{\circledR}$ was given one day prior to CIDR removal most likely reflects the ability of the treatment, in combination with ram introduction, to stimulate a fertile estrus.

It is important to note that the performance of the control ewes in experiment 1 was similar to what was reported by Knights et al. (2001a, b), in which the ewes were synchronized with CIDR devices. However, the control ewes in experiment 1 performed above average compared to some previous studies, in which progestogens were used for estrous synchronization prior to treatment with gonadotropins. For example, $67.6 \%$ of the ewes treated with progesterone alone lambed in the present study, whereas only $45 \%$ of SMB-only treated ewes and $26 \%$ of MGA-only treated ewes lambed in a previous study (Jabbar et al., 1994). The above average performance of the controls ewes could explain why no difference in the percentage of ewes that lambed was observed in experiment 1.

The lambing rate was higher in treated ewes compared to controls when P.G. $600^{\circledR}$ was administered one day prior to CIDR removal. This is in agreement with Zarkawi et al. (1999), who reported that ewes treated with $400 \mathrm{IU}$ of eCG at sponge removal had higher lambing rates compared to ewes treated with a sponge alone, and Zeleke et al. (2005), who reported that ewes administered 300 IU 
of eCG 24 hours prior to sponge removal had significantly higher lambing rates compared to spongetreated ewes.

The effects of P.G. $600^{\circledR}$ on lambing rates might be associated with the method of progestogen priming. Jabbar et al. (1994) primed ewes with SMB or MGA and observed higher lambing rates in P.G. $600^{\circledR}$-treated ewes primed with SMB but not MGA. In the present study, the natural hormone, progesterone, was used, and lambing rates were also increased with P.G. $600^{\circledR}$. Further, the higher lambing rates observed when P.G. $600^{\circledR}$ was administered one day prior to insert removal were probably associated with the cumulative effects of a significantly higher proportion of ewes lambing and a numerically higher prolificacy in ewes treated with P.G. $600^{\circledR}$.

The observed effects of the gonadotropin mixture, P.G. $600^{\circledR}$, on reproductive success in progesterone-treated non-lactating anestrous ewes were presumably a result a few different factors. For example, the timing of injection, either at CIDR device removal (experiment 1) or 24 hours prior to CIDR device removal (experiment 2), appeared to influence the effect of the gonadotropins. By allowing more time for the gonadotropins to facilitate development of the growing follicles and subsequent ovulation of the oocytes, conception rates were increased. This may be a result of higher quality oocytes that were ovulated following treatment with gonadotropins 24 hours prior to CIDR removal (experiment 2; Moor et al., 1984). Further, the additional time of action of the gonadotropins on the ovary could explain the increased proportion of treated ewes that lambed compared to controls in experiment 2.

The dose of gonadotropins used in the current study (240 IU eCG and 120 IU hCG) has not been reported in sheep. In comparison to previous studies that used P.G. $600^{\circledR}$, it appeared that the dose of gonadotropin affected the outcome of the treatment. A higher dose of gonadotropin (400 IU eCG and 200 IU hCG) would presumably lead to more estrogen production by the growing follicles, so one would expect estrous responses to be positively correlated with dose of gonadotropin treatment. However, 
Windorski et al. (2008) observed a lower estrous response in the P.G. $600^{\circledR}$-treated ewes compared to the controls. Using a smaller more moderate dose of gonadotropins ( $240 \mathrm{IU}$ eCG and $120 \mathrm{IU}$ hCG) could be sufficient to facilitate maturation of follicles, while not negatively affecting the pattern of growth and development of the follicle and oocyte, as seen in Moor et al. (1985) when 1,250 IU of eCG was used for superovulation. Further, a more moderate dose of gonadotropin could lead to a small increase in ovulation rate without detrimental effects on fertility or embryonic loss.

In summary, the benefit of P.G. $600^{\circledR}$ may be dependent on the performance of progesteroneonly treated ewes (controls). For example, the gonadotropin mixture increased reproductive performance when the performance of control ewes was low, as seen in experiment 2, but the magnitude of the effect is diminished when the performance of control ewes was higher, as in experiment 1 . Therefore, P.G. $600^{\circledR}$ can be used as an insurance against below than average performance. In addition, it was determined that giving the injection of $3 \mathrm{~mL}$ of P.G. $600^{\circledast}(240 \mathrm{IU}$ eCG and 120 IU hCG) was economically beneficial. 


\section{SUMMARY}

Through breeding ewes out-of-season, producers can take advantage of higher lamb prices, reduce losses of ewes and lambs due to predation and parasitism, and increase productivity of their ewes. To breed ewes out-of-season, estrus must be induced using exogenous hormones. A mixture of gonadotropins, P.G. $600^{\circledR}$ ( $3 \mathrm{~mL} ; 240$ IU eCG and 120 IU hCG), was administered either at CIDR removal (experiment 1 ) or one day prior to CIDR removal (experiment 2 ) to examine its effects on reproductive success in non-lactating anestrous ewes. It was hypothesized that giving a $3 \mathrm{~mL}$ dose of P.G. $600^{\circledR}$ would increase reproductive success in progesterone-treated ewes bred during the anestrous period, thereby potentially leading to an increased profitability of sheep producers.

Ewes were given a 5-day CIDR and assigned randomly to receive P.G. $600^{\circledR}$ (240 IU eCG and 120 IU hCG) at CIDR removal (experiment 1) or one day prior to CIDR removal (experiment 2). At CIDR removal, ewes were exposed to rams, which were fitted with marking harnesses. Data were analyzed using analysis of variance and least squares means were calculated. In experiment 1 , administering $3 \mathrm{~mL}$ of P.G. $600^{\circledR}$ at CIDR removal in non-lactating ewes bred during the anestrous period increased estrous responses (94.2 vs. $79.2 \%$ ) and tended to increase prolificacy (1.67 vs. 1.47) in treated ewes compared to controls. However, in experiment 2, administering P.G. $600^{\circledR}$ one day prior to CIDR removal increased conception rates (51.8 vs. $39.2 \%)$, pregnancy rates to first service ( 45.8 vs. $32.0 \%$ ), the overall percentage of ewes that lambed (61.2 vs. $42.2 \%)$, and lambing rates ( 92.4 vs. $63.6 \%)$ in treated animals compared to controls. Although reproductive success of treated ewes was increased, the responses were still not comparable to those achieved in ewes bred during the breeding season. However, the overall profitability of the enterprise could be increased due to the higher percentage of ewes that lambed. Therefore, additional experiments are needed to evaluate how P.G. $600^{\circledR}$ can further improve the productivity of ewes bred during the anestrous period, while still remaining economically beneficial. 


\section{LITERATURE CITED}

Abba, D. and Lean I.J. (2005). A study of puberty in Romney ewe lambs by oestrus detection, laparoscopy and progesterone assay. J. Cam. Acad. Sci. 5: 29-35.

Adams, N.R., Briegel, J.R., Sanders, M.R., Blackberry, M.A., and Martin, G.B. (1997). Level of nutrition modulates the dynamics of oestradiol feedback on plasma FSH in ovariectomized ewes. Anim. Reprod. Sci. 47: 59-70.

Ainsworth, L. and Shrestha, J.N.B. (1985). Effect of PMSG dosage on the reproductive performance of adult ewes and ewe lambs bred at a progestagen-PMSG synchronized estrus. Theriogenology. 24: 479-487.

Ainsworth, L. and Shrestha, J.N.B. (1987). The reproductive performance of ewe lambs in a controlled environment. Anim. Prod. 44: 233-240.

Ainsworth, L., Heaney, D.P., and Shrestha, J.N.B. (1991). Age at puberty, fertility, and litter size of ewe lambs reared under different photo-regimens. Theriogenology. 36: 401-409.

Al-Mauly, N.Z.N., Bryant, M.J., and Cunningham, F.J. (1991). Effect of the introduction of rams on the pulsatile release of luteinizing hormone and the onset of reproductive activity in ewe lambs. Anim. Prod. 53: 209-214.

Al-Shorepy, S. A. and Notter, D.R. (1996). Genetic variation and covariation for ewe reproduction, lamb growth and lamb scrotal circumference in a fall-lambing sheep flock. J. Anim. Sci. 74: 14901498.

Armstrong, D.T., Pfitzner, A.P., Warnes, G.M. Raph, M.M., and Seamark, R.F. (1983). Endocrine responses of goats after induction of superovulation with PMSG and FSH. J. Reprod. Fertil. 67: 395-401.

Bainbridge, D.R., Deakin, D., and Jabbour, H.N. (1998). Premature luteal regression induced by equine chorionic gonadotropin and estrogen is suppressed by administration of exogenous interferon in red deer (Cervus elaphus). Biol. Reprod. 58: 124-129.

Barrett, D.M., Bartlewski, P.M., Batista-Arteaga, M., Symington, A., and Rawlings, N.C. (2004). Ultrasound and endocrine evaluation of the ovarian response to a single dose of $500 \mathrm{IU}$ of eCG following a 12-day treatment with progestogen-releasing intravaginal sponges in the breeding and non-breeding seasons in ewes. Theriogenology. 61: 311-327.

Bellows, R.A., Pope, A.L., Meyer, R.K., Chapman, A.B., and Casida, L.E. (1963). Physiological mechanisms in nutritionally-induced differences in ovarian activity of mature ewes. J. Anim. Sci. 22: 93-100.

Berardinelli, J.G., Dailey, R.A., Butcher, R.L., and Inskeep, E.K. (1980). Source of circulating progesterone in prepubertal ewes. Biol. Reprod. 22: 233-236. 
Bittman, E.L., Karsch, F.J., and Hopkins, J.W. (1983). Role of the pineal gland in ovine photoperiodism: regulation of seasonal breeding and negative feedback effects of estradiol upon luteinizing hormone secretion. Endocrinology. 30: 329-336.

Bittman, E.L. and Weaver, D.R. (1990). The distribution of melatonin binding sites in the neuroendocrine tissues of the ewe. Biol. Reprod. 113: 986-993.

Boukhliq, R., Adams, N.R., and Martin, G.B. (1996). Effect of nutrition on the balance of production of ovarian and pituitary hormones in ewes. Anim. Reprod. Sci. 45: 59-70.

Britt, J. H., Day, B.N., Webel, S.K., and Brauer, M.A. (1989). Induction of fertile estrus in prepubertal gilts by treatment with a combination of pregnant mare's serum gonadotropin and human chorionic gonadotropin. J. Anim. Sci. 67: 1148-1153.

Buckrell, B.C. (1987). Management of reproduction of sheep. Can. Vet. J. 28: 374-377.

Burfening, P.J. and Van Horn, J.L. (1970). Induction of fertile oestrus in prepubertal ewes during the anoestrous season. J. Reprod. Fertil. 23: 147-150.

Cameron, J., Malpaux, B., and Castonguay, F.W. (2010). Accelerated lambing achieved by a photoperiod regimen consisting of alternating 4-month sequences of long and short days applied year-round. J. Anim. Sci. 88: 3280-3290.

Carpenter, R.H. and Spitzer, J.C. (1981). Response of anestrous ewes to norgestomet and PMSG. Theriogenology. 15: 389-393.

Chupin, D., Cognie, Y., Combarnous, Y., Procureur, R., and Saumande, J., (1987). Effect of purified LH and FSH on ovulation in the cow and ewe. In: Roche, J.F. and O'Callaghan, D. (Eds.), Follicular Growth and Ovulation Rate in Farm Animals. Martinus Nijhoff, The Hague, p. 63-71.

Cline, M.A., Ralston, J.N., Seals, R.C., and Lewis, G.S. (2001). Intervals from norgestomet withdrawal and injection of equine chorionic gonadotropin or P.G. 600 to estrus and ovulation in ewes. J. Anim. Sci. 79: 589-594.

Cole, H.H. and Miller, R.F. (1935). Changes in the reproductive organs of the ewe with some data on their control. Am. J. Anat. 57: 39-97.

Daniel, J.A., Sterle, S.W., McFadin-Buff, E.L., and Keisler, D.H. (2001). Breeding ewes out-of-season using melengestrol acetate, one injection of progesterone, or a controlled internal drug releasing device. Theriogenology. 56: 105-110.

Dardente, H. (2011). Melatonin-dependent timing of seasonal reproduction by the Pars Tuberalis: pivotal roles for long daylengths and thyroid hormones. J. Neuroendocrinology. 24: 249-266. 
Devonish, E.H., Knights, M., and Inskeep, E.K. (2009). Effect of peripheral concentrations of progesterone on ovulation rate and litter size in Barbados Blackbelly ewes. Sheep \& Goat Res. J. 24: $17-25$.

Dixon, A.B., Knights, M., Winkler, J.L., Marsh, D.J., Pate, J.L., Wilson, M.E., Dailey, R.A., Seidel, G., and Inskeep, E.K. (2007). Patterns of late embryonic and fetal mortality and association with several factors in sheep. J. Anim. Sci. 85: 1274- 1284.

Dobson, H., Fergani, C., Routly, J.E., and Smith, R.F. (2012). Effects of stress on reproduction in ewes. Anim. Reprod. Sci. 130: 135-140.

Donovan, A., O'Callaghan, D., Boland, M.P., Karsch, F.J., and Roche, J.F. (1991). The relative importance of social signals from ewes and rams in influencing the timing of the breeding season of ewes. J. Reprod. Fertil. Abstr. Series 7: 30.

Downing, J.A., Joss, J., Connell, P., and Scaramuzzi, R.J. (1995). Ovulation rate and the concentrations of gonadotrophic and metabolic hormones in ewes fed lupin grain. J. Reprod. Fertil. 103: 137-145.

Dumas, Carol Ryan. (2011). "U.S. sheep and lamb markets soar". Capital Press. 19 May 2011 http://www.capitalpress.com/lvstk/CRD-lamb-market-w-chart-052011.

Dunn, T.G. and Kaltenbach, C.C. (1980). Nutrition and the postpartum interval of the ewe, sow and cow. J. Anim. Sci. 51: 29-39.

Dutt, R.H. and Bush, F. (1955). The effect of low environmental temperature on initiation of the breeding season and fertility in sheep. J. Anim. Sci. 14: 885-897.

Dyrmundsson, O.R. (1973). Puberty and early reproductive performance in sheep. I. Ewe lambs. Anim. Abstr. 41: 273-289.

Eilts, B.E. (2005). Ram breeding soundness examination. In: Comparative Theriogenology Course, VMED5361. Louisiana State University School of Veterinary Medicine. http://www.vetmed.Isu.edu.

Evans, G. and Armstrong, D.T. (1983). Reduction in fertilization rate in vitro of oocytes from immature rats induced to superovulate. J. Reprod. Fertil. 70: 131-135.

Fletcher, I.C. and Lindsay, D.R. (1971). Effect of rams on the duration of oestrous behaviour in ewes. J. Reprod. Fertil. 25: 252-259.

Foote, W.C. and Bennett, J.A. (1968) Hormonal induction of fertile mating in the prepuberal ewe. J. Anim. Sci. 27: 1191.

Forcada, F., Abecia, J.A., and Zarazaga, L.A. (1991). A note on the attainment of puberty of September born early maturing ewe lambs in relation to level of nutrition. Anim. Prod. 53: 407-409. 
Forcada, F., Abecia, J.A., and Sierra, I. (1992). Seasonal changes in oestrous activity and ovulation rate in Rasa Aragonesa ewes maintained at two different body condition levels. Small Rumin. Res. 8: 313-324.

Gaskins, C.T., Snowder, G.D., Westman, M.K., and Evans, M. (2005). Influence of body weight, age, and weight gain on fertility and prolificacy in four breeds of ewe lambs. J. Anim. Sci. 83: 1680-1689.

Geytenbeek, P.E., Oldham, C.M., and Gray, S.J. (1984). The induction of ovulation in the post-partum ewe. Proc. Aust. Soc. Anim. Prod. 15: 353-356.

Godley, W.C., Wilson, R.L., and Hurst, V. (1966). Effect of controlled environment on the reproductive performance of ewes. J. Anim. Sci. 25: 212-216.

Goodman, R.L. (1999). Seasonal Reproduction, Mammals. In Encyclopedia of Reproduction (E. Knobil and J.D. Neill, Eds.), Vol. 4, pp. 341-351. Academic Press, California.

Gordon, I. (1983). Controlled breeding of sheep. In: Controlled Breeding of Farm Animals. Permagon Press, Willowdale, Ontario: 1-400.

Gordon, I. (1997). Controlled reproduction in sheep and goats. Cambridge University Press, Wallingford, UK: $178-180$.

Gouletsou, P.G. and Fthenakis, G.C. (2010). Clinical evaluation of reproductive ability of rams. Small Rumin. Res. 92: 45-51.

Hamra, A.H., Massri, Y.G., Marcek, J.M., and Wheaton, J.E. (1986). Plasma progesterone levels in ewes treated with progesterone-controlled internal drug-release dispensers, implants and sponges. Anim. Reprod. Sci. 11: 187-194.

Hamra, A.H., McNally, J.W., Marcek, J.M., Carlson, K.M., and Wheaton, J.E. (1989). Comparison of progesterone sponges, cronolone, sponges and controlled internal drug release dispensers on fertility in anestrous ewes. Anim. Reprod. Sci. 18: 219-226.

Henderson, D.C. and Robinson, J.J. (2000). The reproductive cycle and its manipulation. In: Martin, W.B., Aitken, I.D. Diseases of Sheep. 3rd ed. Oxford: Blackwell Scientific Publications.

Horsley, B.R. (2004). Effect of P.G. 600 on the timing of ovulation in gilts treated with Regu-mate. MSc. Thesis. Virginia Polytechnic Institute and State University.

Hulet, C. V., Voightlander, H.P., Pope, A.L., and Casida, L.E. (1956). The nature of early-season infertility in sheep. J. Anim. Sci. 15: 607-616.

Hunter, G.L. and Lishman, A.W. (1967). Postpartum ovulation and oestrus in spring lambing ewes. J. Reprod. Fertil. 14: 473.

Jabbar, G., Umberger, S.H., and Lewis, G.S. (1994). Melengestrol acetate and norgestomet for the induction of synchronized estrus in seasonally anovular ewes. J. Anim. Sci. 72: 3049-3054. 
Jones, K.G. (2004). Trends in the U.S. Sheep Industry. Agriculture Information Bulletin Number 787, pp. 1-34. www.ers.usda.gov.

Karsch, F.J., Bittman, E.L., Foster, D.L., Goodman, R.L., Legan, S.J., and Robinson, E. (1984). Neuroendocrine basis of seasonal reproduction. Rec. Prog. Horm. Res. 40: 185-232.

Kassam, R., Owen, J.B., and Fadel, I. (1989). The effect of pre-mating nutrition and exposure to the presence of rams on the onset of puberty in Awassi ewe lambs under semi-arid conditions. Anim. Prod. 48: 393-397.

Khaldi, G. (1984). Seasonal changes in ovarian activity, estrous behavior and post-partum estrous length of Barbains ewes: influences of nutritional level and presence of male. Ph.D. Thesis. UST Languedoc, France.

Knight,T.W. and Lynch, P.R. (1980a). Source of ram pheromones that stimulate ovulation in the ewe. Anim. Reprod. Sci. 3: 133-136.

Knight, T.W. and Lynch, P.R. (1980b). The pheromone from rams that stimulates ovulation in the ewe. Proc. Aust. Soc. Anim. Prod. 13: 74-76.

Knight, T.W., McMillan, W.H., Kannegister, S., Sorrenson, E., Ridland, C.J., and Gibb, M. (1989). Mating Romney ewes in November-December using CIDRs and pregnant mare serum gonadotrophin. Proc. N.Z. Soc. Anim. Prod. 49: 255-260.

Knights, M., Hoehn, T., Lewis, P.E., and Inskeep, E.K. (2001a). Effectiveness of intravaginal progesterone inserts and FSH for inducing synchronized estrus and increasing lambing rate in anestrous ewes. J. Anim. Sci. 79: 1120-1131.

Knights, M., Maze, T.D., Bridges, P.J., Lewis, P.E., and Inskeep, E.K. (2001b). Short-term treatment with a controlled internal drug releasing (CIDR) device and FSH to induce fertile estrus and increase prolificacy in anestrous ewes. Theriogenology. 55: 1181-1191.

Knights, M., Baptiste, Q.S., and Lewis, P.E. (2002). Ability of ram introduction to induce LH secretion, estrus and ovulation in fall-born ewe lambs during anestrus. Anim. Reprod. Sci. 69: 199-209.

Knights, M., Baptiste, Q.S., Dixon, A.B., Pate, J.L., Marsh, D.J., Inskeep, E.K., and Lewis, P.E. (2003). Effects of dosage of FSH, vehicle and time of treatment on ovulation rate and prolificacy in ewes during the anestrous season. Small Rumin. Res. 50: 1-9.

Knights, M., Singh-Knights, D., Bourne, G.A., Inskeep, E.K., Lewis, P.E. (2004). Use of the ram effect to induce out of season breeding. In: Proceedings of the $7^{\text {th }}$ World Sheep and Wool Congress 2004, July 17-24, 2004, Quebec, Canada, p. 355-377. 
Knox, R.V., Rodriguez-Zas, S.L., Miller, G.M., Willenburg, K.L., and Robb, J.A. (2001). Administration of P.G. 600 to sows at weaning and the time of ovulation as determined by transrectal ultrasound. J. Anim. Sci. 79: 796-802.

Laster, D.B. and Glimp, H.A. (1972). A note on the effect of ram to ewe ratio on reproductive performance of synchronized ewes. Anim. Prod. 15: 99-102.

Leyva, V., Buckrell, B.C., and Walton, J.S. (1998). Follicular activity and ovulation regulated by exogenous progestogen and PMSG in anestrous ewes. Theriogenology. 50: 377-393.

Lincoln, G.A. and Davidson, W. (1977). The relationship between sexual and aggressive behavior, and pituitary and testicular activity during the seasonal sexual cycle of rams, and the influence of photoperiod. J. Repro. Fertil. 49: 267-276.

Lindsay, D.R., Cognie, Y., Pelletier, J., and Signoret, J.P. (1975). Influence of the presence of rams on the timing of ovulation and discharge of LH in ewes. Physiol. Behav. 15: 423-426.

Lishman, A.W., Stielaw, W.J., and Botha, W.A. (1974). Reproduction in the ewe in relation to plane of nutrition, body mass and change of body mass. I. Incidence of oestrus between lambing and reconception. Agroanimalia. 6: 25.

López-Sebastian, A., Gómez-Brunet, A., Pinilla, A., and Cabrellos, B. (1985). Influencia de la epoca de nucimiento y el effecto de los machos sobre la aparicion de la pubertad en corderas manchegas. ITEA 58: 45-50.

Mac Donnell, H.F. and Crowley, J.P. (1978). The effect of progesterone impregnated sponges on fertility in anoestrous ewes. Vet. Sci. Comm. 2: 115-130.

Mandiki, S.N.M., Bister, J.L., and Paquay, R. (1990). Effects of suckling mode on endocrine control of reproductive activity resumption in Texel ewes lambing in July or November. Theriogenology. 33: 397-413.

Marshall, F.H.A. (1937). On the change over in the oestrous cycle in animals after transference across the equators, with further observations on the incidence of the breeding seasons and the factors controlling sexual periodicity. Proc. Royal Soc. London. 122: 413-428.

Martin, G.M., Oldham, C.M., Cognie, Y., and Pearce, D.T. (1986). The physiological responses of anovulatory ewes to the introduction of rams-a review. Live. Prod. Sci. 15: 219-247.

Martin, G.B. and Walkden-Brown, S.W. (1995). Nutritional influences on reproduction in mature male sheep and goats. J. Reprod. Fertil. Suppl. 49: 437-449.

Mauléon, P. and Dauzier, L. (1965). Variations de durée de l'anoestrus de lactation chez les brebis de race lle-de-France. Ann. Biol. Anim. Biochem. Biophys. 5: 131-141. 
McCracken, J. A., Carlson, J.C., Glew, M.E., Goding, J.R., Baird, D.T., Green, K., and Samuelsson, B. (1972). Prostaglandin F2 $\alpha$ identified as a luteolytic hormone in sheep. Nature (New Biol). 238: 129.

McNatty, K.P., Gibb, M., Dobson, C., and Thurley, D.C. (1981). Evidence that changes in luteinizing hormone secretion regulate the growth of preovulatory follicle in the ewe. J. Endocrinol. 90: 375-398.

McNeilly, A.S. (1997). Lactation and fertility. Journal of Mammary Gland Biology and Neoplasia. 2: 291298.

Memon, M. (1983). Male infertility. Vet. Clin. North Am. 5: 619-632.

Miller, B.G. and Armstrong, D.T. (1981). Effects of a superovulatory dose of pregnant mare serum gonadotrophin on ovarian function, serum estradiol, and progesterone levels and early embryo development in immature rats. Biol. Reprod. 25: 261-271.

Miller, J.E., Bahirathan, M., Lemarie, S.L., Hembry, F.G., Kearney, M.T., and Barras, S.R. (1998). Epidemiology of gastrointestinal nematode parasitism in Suffolk and Gulf Coast Native sheep with special emphasis on relative susceptibility to Haemonchus contortus infection. Vet. Parasitology. 74: 55-74.

Mitchell, L.M., King, M.E., Gebbie, F.E., Ranilla, M.J., and Robinson, J.J. (1998). Resumption of oestrous and ovarian cyclicity during the post-partum period in autumn-lambing ewes is not influenced by age or dietary protein content. Brit. Soc. Anim. Sci. 67: 65-72.

Mock, E.J. and Niswender, G.D. (1983). Differences in the rates of internalization of 125I-labeled human chorionic gonadotropin, luteinizing hormone, and epidermal growth factor by ovine luteal cells. Endocrinology. 113: 259-264.

Moor, R.M., Kruip, Th.A.M., and Green, D. (1984). Intraovarian control of folliculogenesis: limits of superovulation? Theriogenology. 21: 103-116.

Moor, R.M., Osborn, J.C., and Crosby, I.M. (1985). Gonadotrophin-induced abnormalities in sheep oocytes after superovulation. J. Reprod. Fertil. 74: 167-172.

Murdoch, W.J. (1985). Follicular determinants of ovulation in the ewe. Dom. Anim. Endocrin. 2: 105 121.

Noakes, E.D., Parkinson, J.T., England, G.C.W. (2001). Fertility and infertility in male animals. In: England, G.C.W., Arthur, G.H., Noakes, D.E., Parkinson, T.J. (Eds.), Arthur's Veterinary Reproduction and Obstetrics, $8^{\text {th }}$ ed. Saunders, Philadelphia, pp. 695-750.

Notter, D.R., Lucas, J.R., and McClougherty, F.S. (1981). The accuracy of estimation of testis weight from in-situ testis measures in ram lambs. Theriogenology. 15: 227-232. 
Notter, D. R. (2002). Opportunities to reduce seasonality of breeding in sheep by selection. Sheep Goat Res. J. 17: 20-32.

Oldham, C.M., Martin, G.B., and Knight, T.W. (1978). Stimulation of the seasonally anovular Merinos ewe by rams. I. Time from introduction of the rams to the preovulatory surge and ovulation. Anim. Reprod. Sci. 1: 283-290.

Oldham, C.M. and Martin, G.B. (1979). Stimulation of seasonally anovular Merino ewes by rams. II. Premature regression of ram-induced corpora lutea. Anim. Reprod. Sci. 1: 291.

Oldham, C.M. and Gray, S.J. (1984). The 'ram effect' will advance puberty in 9-10 month old Merino ewes independent of their season of birth. Anim. Prod. Aust. 15: 727.

Olster, D.H. and Foster, D.L. (1988).Control of gonadotrophin secretion during the prepubertal and seasonal transitions in the male sheep. J. Reprod. Fertil. 82: 179-191.

Ortavant, R. (1959). Spermatogensis and Morphology of the spermatozoa. In: Reproduction in Domestic Animals, eds. Cole, H.H and Cupps, P.T. (1 ${ }^{\text {st }}$ edn). Academic Press, N.Y., 11: 1-50.

Parr, R.A. (1987). Overfeeding during early pregnancy reduces peripheral progesterone concentration and pregnancy rate in sheep. J. Reprod. Fertil. 80: 317-320.

Parsons, S.D. and Hunter, G.L. (1967). Effect of the ram on duration of oestrus in the ewe. J. Reprod. Fertil. 14: 61-70.

Pearce, D.T., Martin, G.B., and Oldham, C.M. (1985). Corpora lutea with short life-span induced by rams in seasonally anovulatory ewes are prevented by progesterone delaying the preovulatory surge of LH. J. Reprod. Fertil. 75: 79.

Pelletier, J. and Almeida, G. (1987). Short light cycles induce persistent reproductive activity in lle-de France rams. J. Reprod. Fertil. Suppl. 34: 215-226.

Poindron, P., Cognie, Y., Gayerie, F., Orgeur, P., Oldham, C.M., and Ravault, J.P. (1980). Changes in gonadotrophins and prolactin levels in isolated (seasonally or lactationally) anovular ewes associated with ovulation caused by introduction of rams. Physiol. Behav. 25: 227-236.

Powell, M.R., Kaps, M., Lamberson, W.R., and Keisler, D.K. (1996). Use of melengestrol acetate-based treatments to induce and synchronize estrus in seasonally anestrous ewes. J. Anim. Sci. 74: 2292-2302.

Quinlivan, T. D. (1966). Estimates of pre- and perinatal mortality in the New Zealand Romney Marsh ewe. J. Reprod. Fertil. 11: 379-390.

Ravindra, J.P. and Rawlings, N.C. (1997). Ovarian follicular dynamics in ewes during the transition from anestrus to the breeding season. J. Reprod. Fertil. 110: 279-289. 
Richards, J.S. (1980). Maturation of ovarian follicles: action and interactions of pituitary and ovarian hormones on follicular cell differentiation. Physiol. Rev. 60: 51-89.

Robinson, T.J. and Smith, J.F. (1967). The evaluation of S G-9880-impregnated intravaginal sponges used with or without PMS for the advancement of the breeding season of British breed ewes. In: T.J. Robinson (Ed.) The Control of the Ovarian Cycle in Sheep. Sidney University Press, Signey, N.S.W., Australia: 144-157.

Rosa, H.J.D. and Bryant, M.J. (2002). The 'ram effect' as a way of modifying the reproductive activity in the ewe. Small Rumin. Res. 45: 1-16.

Safranski, T. J., Lamberson, W.R., and Keisler, D.H. (1992). Use of melengestrol acetate and gonadotropins to induce fertile estrus in seasonally anestrous ewes. J. Anim. Sci. 70: 2935-2941.

Sargison, N.D. (2008). Sheep Flock Health. A Planned Approach. Blackwell, Oxford: 1-136.

Schanbacher, B.D. and Lunstra, D.D. (1976). Seasonal changes in sexual activity and serum levels of LH and testosterone in Finnish Landrace and Suffolk rams. J. Anim. Sci. 43: 644-650.

Schoenian, S. (2011). "A beginner's guide to raising sheep." Sheep 201, December 2012. http://www.sheep101.info/201/ramrepro.html.

Schrick, F.N., and Inskeep, E.K. (1993). Determination of early pregnancy in ewes utilizing transrectal ultrasonography. Theriogenology. 40: 295-306.

Senger, P.L. (2003) Pathways to Pregnancy and Parturition. Pullman, WA: Current Conceptions, Inc.: 160200.

Shackell, G.H., Kelly, R.W., and Allison, A.T. (1977). Seasonal variation in libido of rams. New Zealand J. Exp. Agric. 5: 121-122.

Shiflett, J.S., Williams, G., and Rodgers, P. (2010). "Nontraditional lamb market in the United States: Characteristics and marketing strategies." Report for the American Sheep Industry Association.

Silva, L. and Ungerfeld, R. (2006). Reproductive response in suckling Corriedale ewes to the ram effect during the non-breeding season: effect of postpartum condition and the use of medroxyprogesterone priming. Trop. Anim. Health Prod. 38: 365-369.

Singh, D. (2000). An analysis of the management decisions of sheep producers in West Virginia. Unpublished MSc. Thesis. West Virginia University: 1-70.

Singh-Knights, D. (2003). An analysis of West Virginia lamb marketing alternatives. Unpublished PhD. Dissertation. West Virginia University: 10-58.

Sirjani, M.A., Shahir, M.H., Kohram, H., Eskandarinasab, M.P., and Moakhar H.K. (2011). The effects of pregnant mare serum gonadotropin (PMSG) injection a day prior or at controlled intravaginal 
drug-releasing (CIDR) removal on multiple births in Afshari ewes. African J. Biotechnology. 10: 12363-12367.

Smith, I.D. (1964). Post-parturient anoestrus in the Peppin Merino in western Queensland. Australian Vet. J. 40: 199.

Smith, I.D. (1966). Oestrous activity in Merino ewes in western Queensland. Proc. Aust. Soc. Anim. Prod. 6: 69-79.

Smith, J.F., Cruickshank, G.J., McGowan, L.T., Parr, J., and Mortimer, B.J. (1988). Seasonal changes in oestrus, ovulation and conception of Coopworth ewes treated with CIDRs and PMSG. Proc. N.Z. Soc. Anim. Prod. 48: 99-102.

Smith, J.F. and Knight, T.W. (1998). Reproductive management of sheep. In: Fielden, E.D., Smith, J.F. (Eds.), Reproductive Management of Grazing Ruminants in New Zealand. New Zealand Society of Animal Production, Hamilton, pp. 113-144.

Sunderland, S.J., O'Callaghan, D., Boland, M.P., and Roche, J.F. (1990). Social cues can alter the timing of reproductive transitions in ewes. J. Reprod. Fertil. Abstr. Series 5: 28.

Thwaites, C.J. (1965). Photoperiodic control of breeding activity in the Southdown ewe with particular reference to the effects of an equatorial light regime. J. Agric. Sci. 65: 57-64.

Umberger, S.H. and Lewis, G.S. (1992). Melengestrol acetate (MGA) for estrous synchronization and induction of estrus in spring-breeding ewes. Sheep Res. J. 8: 59.

Underwood, E.J., Shier, F.L., and Davenport, N. (1944). Studies in sheep husbandry in W.A.V. The breeding season in Merino, crossbred and British breed ewes in the agricultural districts. J. Agric. (Western Australia) Series 2. 11: 135-143.

Ungerfeld, R., Pinczak, A., Forsberg, M., and Rubianes, E. (2002). Ovarian and endocrine responses of Corriedale ewes to ram effect in the non-breeding season. Can. J. Anim. Sci. 82: 599-602.

Ungerfeld, R., Forsberg, M., and Rubianes, E. (2004). Overview of the response of anoestrous ewes to the ram effect. Reprod. Fertil. Dev. 16: 479-490.

Vesely, J.A. and Swierstra, E.E. (1987).Reproductive traits of ewe lambs representing eight genetic types born in winter, spring, summer and fall. J. Anim. Sci. 65: 1195-1200.

Vivien-Roels, B. and Pévet, P. (1983). The pineal gland and the synchronization of reproductive cycles with variations of the environmental climatic conditions, with special reference to temperature. Pineal Res. Rev. 1: 91-143.

Walker, S.K., Smith, D.H., and Little, D.L. (1984). Artificial insemination and transfer of embryos by laparoscopy. In: Reproduction in Sheep. Lindsay, D.R. and Pearce, D.T., eds. New York: Cambridge Press. 
Walker, R., Leamaster, B., Stellflug, J., and Biberstein, E. (1986). Association of age with the distribution of epididymal lesions and etiologic agent. J. Am. Vet. Med. Assoc. 4: 393-396.

Welch, R.A.S., Andrews, W.D., Barnes, D.R., Bremner, K., and Harvey, T.G. (1984). CIDR dispensers for oestrus and ovulation control in sheep. In: Proc. 10th Int. Congress on Animal Reproduction and Artificial Insemination. 3: Urbana-Champaign: University of Illinois; 354-355.

Welch, R.A.S. (1985a). Oestrus synchronization with CIDR dispensers and artificial insemination of Perendale ewes. New Zealand Ministry of Agriculture \& Fisheries, Agric. Res. Div. Annu. Rep. 1983/84: 58.

Welch, R.A.S. (1985b). Development of CIDR dispensers for use in nulliparous ewes. New Zealand Ministryof Agriculture \& Fisheries, Agric. Res. Div. Annu. Rep. 1983/84: 58.

Wheaton, J.E., Windels, J.F., and Johnston, L.J. (1992). Accelerated lambing using exogenous progesterone and the ram effect. J. Anim. Sci. 70: 2628-2635.

Wildeus, S. (2000). Current concepts in synchronization of estrus: Sheep and goats. J. Anim. Sci. 77: 1-14.

Windorski, E.J., Schauer, C.S., Wurst, A.K., Inskeep, E.K., and Luther, J.S. (2008). Effects of melengestrol acetate and P.G. $600^{\circledR}$ on fertility in Rambouillet ewes outside the natural breeding season. Theriogenology. 70: 227-232.

Wodzicka-Tomaszewska, M., Hutchinson, J.C.D., and Bennett, J.W. (1967). Control of the annual rhythm of breeding in ewes: effect of an equatorial day length with reversed thermal seasons. J. Agric. Sci. Camb. 68: 61-67.

Wooster, C. and Hansen, G. (2005). Living with Sheep: Everything You Need to Know to Raise Your Own Flock. Guilford, Connecticut: The Lyons Press. ISBN 1-59228-531-7.

Wright, P.J., Geytenbeek, P.E., Clarke, I.J., and Hoskinson, R.M. (1989). The efficacy of ram introduction, GnRH administration, and immunization against androstenedione and oestrone for the induction of oestrus and ovulation in anoestrous post-partum ewes. Anim. Reprod.Sci. 21: 237 247.

Wright, P.J., Geytenbeek, P.E., and Clarke, I.J. (1990). The influence of nutrient status of post-partum ewes on ovarian cyclicity and on the oestrous and ovulatory responses to ram introduction. Anim. Reprod. Sci. 23: 293-303.

WVDA (West Virginia Department of Agriculture). (2010). West Virginia Bulletin No. 41. USDA-NSAA \& West Virginia Field Office, Charleston, WV, USA.

Yellon, S.M. and Foster, D.L. (1985). Alternate photoperiods time puberty in the female lamb. Endocrinology. 116: 2090-2097. 
Zarkawi, M., Al-Merestani, M.R., and Wardeh, M.F. (1999). Induction of synchronized oestrous and early pregnancy diagnosis in Syrian Awassi ewes, bred outside the breeding season. Small Rumin. Res. 33: 99-102.

Zeleke, M., Greyling, J.P.C., Schwalback, L.M.J., Muller, T., and Erasmus, J.A. (2005). Effect of progestagen and PMSG on oestrous synchronization and fertility in Dorper ewes during the transition period. Small Rumin. Res. 56: 47-53.

Zimbelman, R. G. (1963). Inhibition of estrus in ewes with oral progestogens. J. Anim. Sci. 22: 868 (Abstr.).

Zonturlu, A.K., Ozyurtlu, N., and Kacar, C. (2011). Effect of different doses PMSG on estrus synchronization and fertility in Awassi ewes synchronized with progesterone during the transition period. Kafkas Univ. Vet. Fak. Derg. 17: 125-129. 


\section{VITA}

\section{Kellie Nicole D’Souza}

Birthplace. Morgantown, WV

Date of Birth November 4, 1987

Schools Attended:

Woodburn Elementary $.1992-1998$ Morgantown, WV

Cheat Lake Middle School. $.1998-2002$ Morgantown, WV

University High School. $.2002-2006$ Morgantown, WV

West Virginia University $.2006-2013$ Morgantown, WV

Degrees Received:

Bachelor of Science in Animal and Nutritional Sciences,

West Virginia University, 2010

Master of Science in Reproductive Physiology,

West Virginia University, 2013 


\section{APPENDIX}

\begin{tabular}{|l|c|c|c|c|c|}
\hline Source & $\begin{array}{c}\text { Degrees of } \\
\text { Freedom }\end{array}$ & Sum of Squares & Mean Square & F Value & Pr $>$ F \\
\hline P.G.600 & 1 & 10.29719540 & 10.29719540 & 17.14 & $<.0001$ \\
\hline FARM & 7 & 65.44269786 & 9.34895684 & 15.57 & $<.0001$ \\
\hline FARM * P.G.600 & 7 & 10.29031008 & 1.47004430 & 2.45 & 0.0178 \\
\hline
\end{tabular}

This table represents an analysis of variance for the lambing rate in Experiment 2. 